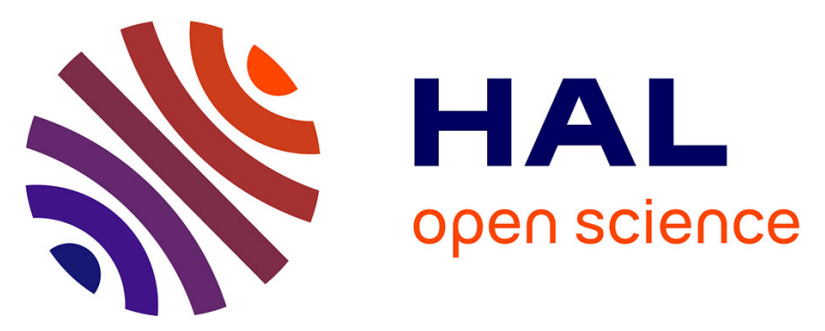

\title{
Understanding the torrefaction of woody and agricultural biomasses through their extracted macromolecular components. Part 2: Torrefaction model
}

María González Martínez, Capucine Dupont, Andrés Anca-Couce, Denilson da Silva Perez, Guillaume Boissonnet, Sébastien Thiery, Xuan Mi Meyer, Christophe Gourdon

\section{To cite this version:}

María González Martínez, Capucine Dupont, Andrés Anca-Couce, Denilson da Silva Perez, Guillaume Boissonnet, et al.. Understanding the torrefaction of woody and agricultural biomasses through their extracted macromolecular components. Part 2: Torrefaction model. Energy, 2020, 210, pp.118451. 10.1016/j.energy.2020.118451 . hal-02918985

\section{HAL Id: hal-02918985 \\ https://imt-mines-albi.hal.science/hal-02918985}

Submitted on 2 Sep 2020

HAL is a multi-disciplinary open access archive for the deposit and dissemination of scientific research documents, whether they are published or not. The documents may come from teaching and research institutions in France or abroad, or from public or private research centers.
L'archive ouverte pluridisciplinaire HAL, est destinée au dépôt et à la diffusion de documents scientifiques de niveau recherche, publiés ou non, émanant des établissements d'enseignement et de recherche français ou étrangers, des laboratoires publics ou privés. 


\title{
Understanding the torrefaction of woody and agricultural biomasses through their extracted macromolecular components. Part 2: Torrefaction model
}

\author{
María González Martínez a, b, c, *, Capucine Dupont ${ }^{\mathrm{d}}$, Andrés Anca-Couce ${ }^{\mathrm{e}}$, \\ Denilson da Silva Perez ${ }^{\mathrm{f}}$, Guillaume Boissonnet ${ }^{\mathrm{c}}$, Sébastien Thiéry ${ }^{\mathrm{c}}$, Xuân-mi Meyer ${ }^{\mathrm{b}}$, \\ Christophe Gourdon ${ }^{\mathrm{b}}$ \\ a Université de Toulouse, IMT Mines Albi, RAPSODEE CNRS UMR-5302, Campus Jarlard, F-81013 Albi Cedex 09, France \\ ${ }^{\mathrm{b}}$ Laboratoire de Génie Chimique, Université de Toulouse, CNRS, INPT, UPS, Toulouse, France \\ ${ }^{\mathrm{c}}$ Université Grenoble Alpes, CEA, Laboratory of Bioresources Preparation (LPB), Grenoble, France \\ d IHE Delft Institute for Water Education, Department of Environmental Engineering and Water Technology, Delft, the Netherlands \\ e Institute of Thermal Engineering, Graz University of Technology, Inffeldgasse 25b, 8010, Graz, Austria \\ ${ }^{\mathrm{f}}$ FCBA, InTechFibres Division, CS 90251, 38044, Grenoble, France
}

Keywords:

Biomass

Torrefaction

Solid kinetics

Polysaccharides

Lignin

\section{A B S T R A C T}

A new torrefaction model was proposed for predicting solid mass loss in torrefaction as a function of biomass main macromolecular composition and type, as well as on the operating conditions. To do this, solid degradation kinetics were modelled following a 2-successive reaction scheme for each macrocompound and the additive modelling approach through biomass macromolecular component behavior in torrefaction proposed by Nocquet et al. (2014). The use of extracted fractions from different woody and agricultural biomass species (ash-wood, beech, miscanthus, pine and wheat straw) instead of commercial compounds increased the accuracy of the prediction of solid kinetics in biomass torrefaction. The validation of the proposed model with 9 raw biomasses in torrefaction showed an accurate prediction for woods, while the prediction for agricultural biomasses was acceptable.

\section{Introduction}

Torrefaction is a thermochemical conversion treatment suitable for dry biomasses, occurring between 200 and 300 to $350{ }^{\circ} \mathrm{C}$ under a default-oxygen atmosphere from several tens of minutes to $1 \mathrm{~h}$. As a result, a torrefied solid is produced, whose properties are close to those of coal in terms of heating value, flowability, grindability and hydrophobicity. At the same time, gaseous products are released, including permanent gases, water and volatile species [1].

The proportion and the properties of the torrefied solid and the gaseous species produced are mainly dependent on temperature and time [2-4]. Furthermore, biomass main macromolecular

* Corresponding author. Université de Toulouse, IMT Mines Albi, RAPSODEE CNRS UMR-5302, Campus Jarlard, F-81013 Albi Cedex 09, France.

E-mail address: maria.gonzalez_martinez@mines-albi.fr (M. González Martínez) composition in cellulose, hemicelluloses and lignin strongly impacts the yield and the nature of the torrefaction products [3,5-7]. The influence of extractives and ash present in biomass still remains controversial in the torrefaction temperature range [8-10]. While extractives are supposed to be mostly released below $200^{\circ} \mathrm{C}$ $[11,12]$, inorganic elements might catalyze thermochemical conversion, but rather at higher temperatures corresponding to pyrolysis or under gasification conditions [13-15].

Up to know, the proposed modelling schemes for pyrolysis and torrefaction were based on a single or several consecutive or parallel reactions, either for biomass or for its macromolecular components [16-20]. A review of the models proposed in literature is provided in Table 1 . Mild pyrolysis models were also considered as torrefaction temperature range partly overlaps the lower pyrolysis temperatures [21-23].

First pyrolysis models were focused on cellulose behavior $[24,25]$. They were based on a first formation step of a called "active cellulose", whose nature still remains controversial [16]. A recent 


\begin{tabular}{|c|c|}
\hline \multicolumn{2}{|c|}{ Abbreviations } \\
\hline E & activation energy $(\mathrm{J} / \mathrm{mol})$ \\
\hline$\varepsilon_{a}$ & mean absolute error \\
\hline$\varepsilon_{r}$ & mean relative error \\
\hline$F$ & $\begin{array}{l}\text { function minimized by least square fitting for the } \\
\text { kinetic parameters determination }\end{array}$ \\
\hline$k$ & kinetic constant $\left(\mathrm{s}^{-1}\right)$ \\
\hline$k_{0}$ & pre-exponential factor $\left(\mathrm{s}^{-1}\right)$ \\
\hline$R$ & ideal gas constant $\left(8.314 \mathrm{~J} \mathrm{~mol}^{-1} \mathrm{~K}^{-1}\right)$ \\
\hline$T$ & temperature $(\mathrm{K})$ \\
\hline$t_{i}, T_{i}$ & : instantaneous values of time and temperature \\
\hline$m_{j}\left(t_{i}, T_{i}\right)$ & $\begin{array}{l}\text { : instantaneous remaining solid mass of } j \text {, where } j \\
\text { can be replaced by C («cellulose»), } \mathrm{C}^{\mathrm{I}} \text { («cellulose } \\
\mathrm{I} »), \mathrm{C}^{\mathrm{II}}(« \text { cellulose II»), DMSO } \mathrm{r}(« \mathrm{DMSO} \text { residue»), } \\
\text { exp (experimental), Glu (glucan), } \mathrm{H}_{1} \\
\text { («hemicelluloses } 1 »), \mathrm{H}_{2}(« \text { hemicelluloses } 2 »), \mathrm{H}_{\mathrm{T}} \\
\text { («total hemicelluloses»), } \mathrm{L}(« \text { lignin»), mod (model } \\
\text { prediction), rb (raw biomass). In all cases } m_{j}(0 s \text {, } \\
273 \mathrm{~K})=1\end{array}$ \\
\hline$x_{j, k}$ & 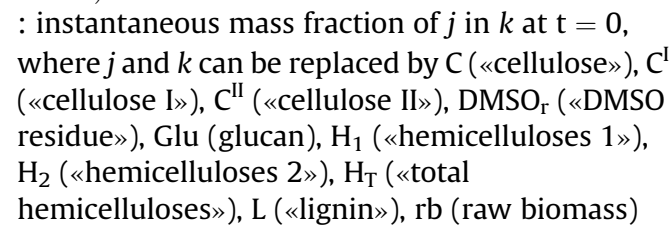 \\
\hline$w m f$ & : weight-moisture-free basis \\
\hline
\end{tabular}

study has associated the activation of crystalline cellulose to the formation of reducing end groups in this polymer [26]. Shafizadeh and Chin proposed the first biomass pyrolysis model in 1977, which consisted of a global scheme of three competitive parallel reactions, the main products being gas, liquids (tar) and char. Then, Koufopanos et al. modified this model by adding an intermediate mechanism about gas and condensable species formation [27].

Pyrolysis model development was typically based on lumped components, for which kinetic parameters were fitted with experimental data [16]. To do this, a first order reaction rate was typically supposed for a sequence of simultaneous and/or consecutive reactions of known or representative stoichiometry. The kinetic scheme of 2-succesive-step model developed by Di Blasi and Lanzetta [28] was one of the most frequently used. It is based on the competition between the formation of volatiles and solid products at each step of the reaction. Even if it was initially developed for xylan pyrolysis, it was then applied to biomass and other macromolecular components pyrolysis [7,29-32] and torrefaction [7,33]. Bates and Ghoniem proposed to calculate the volatile species composition for each reaction of the Di Blasi scheme for willow [34].

Kinetic pyrolysis models based on lumped components were progressively developed to increase the level of detail of the description of biomass transformation. In this sense, molecularbased kinetic models were developed, in parallel to kinetic models based on lumped components with a higher level of complexity. Thanks to molecular-based models, kinetic parameters can be calculated for each chemical reaction involved in biomass transformation, which contributes in a deep description of the phenomena involved [35]. However, the main challenge to their development is achieving an accurate description of biomass composition, especially in the case of hemicelluloses. A simple but effective description of beech transformation through torrefaction was proposed by Nocquet et al. [29]. His torrefaction model is based the additive behavior in torrefaction of commercial cellulose, xylan and lignin, and showed interesting results in predicting solid mass loss and volatile species composition for beech torrefaction. Molecular-based models that can be applied for torrefaction were developed by Vinu and Broadbelt for fast pyrolysis cellulose and glucose-based carbohydrates [36], by Klein et al. for lignin fast pyrolysis [37] and biomass gasification [38], as well as by Norinaga et al. for cellulose [39], wood [40] and lignin pyrolysis [41]. Even if these models lead to a detailed description of the volatile species formed, they are based either on model molecules or on commercial compounds [42].

Ranzi's group proposed a more detailed approach to pyrolysis (and therefore torrefaction) modelling through lumped stoichiometric reactions. Its model consists of a multicomponent mechanism based on the superposition of the pyrolysis sub-mechanisms of cellulose, hemicellulose and lignin [43,44]. Solid kinetics, as well as the production of volatile species, were predicted for woods by considering their macromolecular and elemental composition $[45,46]$. However, the main limitations of Ranzi's model were considering xylan as representative of hemicelluloses, neglecting interactions between macromolecular components and inorganic elements in biomass, as they might play a role at the pyrolysis temperature range, as well as secondary charring reactions [16]. Anca-Couce introduced some modifications to Ranzi's model $[44,47,48]$, in particular the charring reactions description, which is especially relevant for slow processes as torrefaction, and to some extent the influence of the inorganic elements [16,49]. This modified model was applied by Anca-Couce et al. for torrefaction as well as slow and intermediate pyrolysis [49-51]. Later, Dussan et al. contributed to this model by detailing the transformation mechanism of hemicelluloses and lignin. This description was based on five model compounds representing hemicelluloses main sugar units from woody, herbaceous and agricultural biomasses (xylan with acetyl and 4-methyl-d-glucuronic acid groups, arabinoxylan, xyloglucan, glucomannan and $\beta$-glucan). As a result, pentose and hexose-based sugar transformation mechanisms were described [52]. Lignin was defined through dimeric pseudo-components with phenolic functionalities based on two of the lignin base units, namely, $p$-hydroxyphenyl, guaiacyl and syringyl groups, linked through $\beta-0-4^{\prime}$ aryl ether bonds [53]. Dussan's lignin model accurately described heating rate and temperature influence on the product distribution, as well as monoaromatic content in the volatile fraction.

The objective of the present work is to propose a kinetic model able to predict solid mass loss in torrefaction as a function of the biomass type and its main macromolecular composition of cellulose, hemicelluloses and lignin, as well as of the main operating conditions, namely time and temperature. This model aims to contribute in describing biomass through more representative cellulose, hemicelluloses and lignin fractions, which were extracted from ash-wood, beech, miscanthus, pine and wheat straw, instead of using commercial compounds. However, the detailed chemical reactions involved in the mechanisms of transformation of biomass through torrefaction were not assessed in this work. The experimental results of torrefaction of extracted compounds were presented in the first part of this paper [54] and here kinetics are derived and employed to predict biomass torrefaction. The proposed model, based on the additive experimental behavior of the extracted fractions in torrefaction, was compared to previous models in the literature and then validated with nine additional woody and agricultural biomass samples. 


\section{Model development}

The proposed torrefaction model was based on the additivity of the behavior of cellulose, hemicelluloses and lignin in torrefaction, as suggested by Nocquet et al. [29]. The main difference with Nocquet's model is that extracted fractions from five biomasses were considered, instead of commercial compounds. Two levels were defined in the present model in function of the extracted fractions selected for representing biomass main macromolecular components.

\subsection{First-level model}

In this first-level model, the extracted fractions identified as « cellulose II» $\left(\mathrm{C}^{\mathrm{II}}\right)$, «hemicelluloses 1 » $\left(\mathrm{H}_{1}\right)$ and «lignin» $(\mathrm{L})$ were considered as the representative main macromolecular components for each biomass. The so-called "additive model" is based on the sum of the behavior of these extracted fractions, analyzed in the in part 1 , weighted by the proportions of the corresponding main macromolecular components on each raw biomass (Eq. (1), Table 2).

$$
\begin{aligned}
m_{r b}\left(t_{i}, T_{i}\right)= & x_{C, r b} m_{C^{I I}}\left(t_{i}, T_{i}\right)+x_{H, r b} m_{H_{1}}\left(t_{i}, T_{i}\right)+x_{L, r b} m_{L}\left(t_{i}, T_{i}\right) \\
& T_{i} \in[200,300]^{\circ} \mathrm{C}
\end{aligned}
$$

Kinetics of solid transformation through torrefaction for the extracted fractions were described following the structure of the 2succesive step kinetic model proposed by Di Blasi and Lanzetta (Eq. (1)).

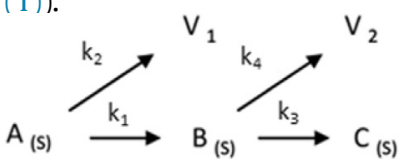

In this model, $A, B$ and $C$ represent solid species, while $V_{1}$ and $V_{2}$ corresponds to gaseous species. The kinetic constants of each chemical reaction are represented by $\mathrm{k}_{1}, \mathrm{k}_{2}, \mathrm{k}_{3}$ and $\mathrm{k}_{4}$. It was supposed that all reactions order is 1 and that the Arrhenius law governs the kinetics of the 4 reactions of the proposed scheme.

$k=k_{0} \exp \left(\frac{-E}{R T}\right)$

\subsubsection{Kinetic parameter calculations}

The kinetic parameters of the model were identified with Matlab $\AA$ for each extracted fraction per biomass by least square fitting (Table 3). To do this, the function F representing the difference between the modelled and the experimental remaining solid mass (Eq. (4)) was minimized. The initialization was carried out with the values of the Nocquet's model parameters [29].

$F=\sum_{t_{i}, T_{i}}\left|m_{\text {mod }}\left(t_{i}, T_{i}\right)-m_{\exp }\left(t_{i}, T_{i}\right)\right|$

Mean absolute $\left(\varepsilon_{\mathrm{a}}\right)$ and relative $\left(\varepsilon_{\mathrm{r}}\right)$ errors, expressed as the average of the square of relative errors, were calculated (Eqs. (5) and (6)).

Mean $\varepsilon_{a}=\frac{\sum_{i=1}^{n}\left(m_{\text {mod }}\left(t_{i}, T_{i}\right)-m_{\exp }\left(t_{i}, T_{i}\right)\right)^{2}}{n}$
Mean $\varepsilon_{r}=\frac{\sum_{i=1}^{n}\left(\frac{m_{\bmod }\left(t_{i}, T_{i}\right)-m_{\exp }\left(t_{i}, T_{i}\right)}{m_{\exp }\left(t_{i}, T_{i}\right)}\right)^{2}}{n}$

Kinetic constants for the four reactions of the kinetic scheme of the torrefaction model were calculated for each extracted macromolecular component by considering a typical torrefaction temperature range $\left(200-300^{\circ} \mathrm{C}\right)$ and a first order chemical reaction (In $\mathrm{k}$ versus $1 / \mathrm{T}$, presented in the Supplementary Material, Figures S1 to S4). The calculated kinetic constants for $\mathrm{C}^{\mathrm{Il}}$ fractions were more impacted by the influence of temperature than those of $\mathrm{H}_{1}$ and $\mathrm{L}$ fractions. This behavior was coherent with the enhanced degradation of cellulose around $300{ }^{\circ} \mathrm{C}$. Oppositely, the calculated kinetic constants for $\mathrm{L}$ fractions were not much affected by temperature, except in the case of pine. This behavior was in agreement with their low degradation at the torrefaction temperatures.

The obtained parameters remained generally the same order of magnitude to those proposed by Nocquet in the case of beech [29], except for lignin. The low mean absolute and relative errors obtained when fitting the kinetic parameters indicated the correct fitting of the experimental data by the model (Table 3). However, in the case of $\mathrm{C}^{\mathrm{II}}$ fractions, the model predicted a starting degradation temperature of some degrees higher than that experimentally observed. Furthermore, the fitting of the model parameters was very sensitive to the initialization values. In the case of $\mathrm{H}_{1}$ fractions, the model was not able to accurately predict the slight solid mass loss observed in the isothermal torrefaction step for miscanthus, pine and wheat straw. Anyhow the maximum relative error is of $0.3 \%$, which is satisfactory.

In general, calculated activation energies were similar for all reactions for $C^{\text {II }}$ from all species. This might imply that the mechanism of cellulose decomposition did not depend on the biomass type. Activation energies for reaction 4 for ash-wood and pine $\mathrm{C}^{\mathrm{II}}$ fractions were higher than that of the other samples. This may suggest that a higher energy is required to break the chemical bonds involved in the transformations associated to this step for these species. This behavior seems coherent with the more resilient structure of woods compared to that of agricultural crops.

In the case of $\mathrm{H}_{1}$ fractions, the obtained activation energies were slightly lower for reaction 1 and similar for the other reactions. Furthermore, the highest variability was found for reaction 1 . These results might indicate that hemicelluloses degradation would be governed by differences in sugar composition, which are dependent on biomass type. Thus, this difference seemed to present a higher impact in the beginning of hemicelluloses transformation, which is in agreement with their degradation from low to intermediate torrefaction temperatures.

Activation energies for $\mathrm{L}$ fractions appeared to be rather heterogeneous for all reactions and samples. The low activation energy of reaction 2 for pine $L$ fraction was remarkable but, according to the Arrhenius law, needs to be linked to the low $\mathrm{k}_{0}$ obtained and it shows none dependence of temperature. A higher activation energy was obtained for reaction 4 , which may be related to the low extent of the devolatilization of lignin in the torrefaction temperature range.

The average activation energy per chemical reaction was calculated for all extracted fractions (Fig. 1). For all biomass species, this value was systematically higher for the $C^{\mathrm{II}}$ fraction, followed by $\mathrm{H}_{1}$ fraction and $\mathrm{L}$ fraction. The intermediate steps (reactions 2 and 3 ) presented the highest difference in the activation energies. Globally, a low standard deviation was found for all activation energies, except for $\mathrm{C}^{\mathrm{II}}$ fractions in reaction 4 and for L fractions, as well as to a lower extent for $\mathrm{H}_{1}$ in reaction 1 . 
Table 1

Review of the evolution of main pyrolysis models applicable to torrefaction.

\begin{tabular}{|c|c|c|c|c|c|c|}
\hline Name & Year & Scheme & Process & $\mathrm{T}\left({ }^{\circ} \mathrm{C}\right)$ & Ref. & Used in \\
\hline Kilzer, Broido & $\begin{array}{l}1969 \\
-1975\end{array}$ & cellulose $\stackrel{\mathrm{k} 2}{\longrightarrow}$ char + low molecular weight volatiles & Cellulose pyrolysis & 370 & {$[55,56]$} & \\
\hline Arseneau & 1971 & 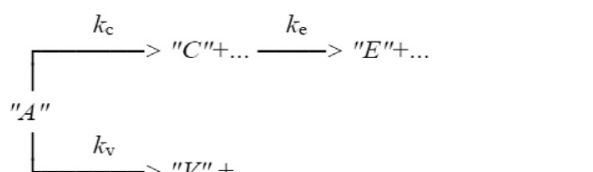 & $\begin{array}{l}\text { Cellulose thermal } \\
\text { decomposition }\end{array}$ & $200-270$ & [57] & [58] \\
\hline
\end{tabular}

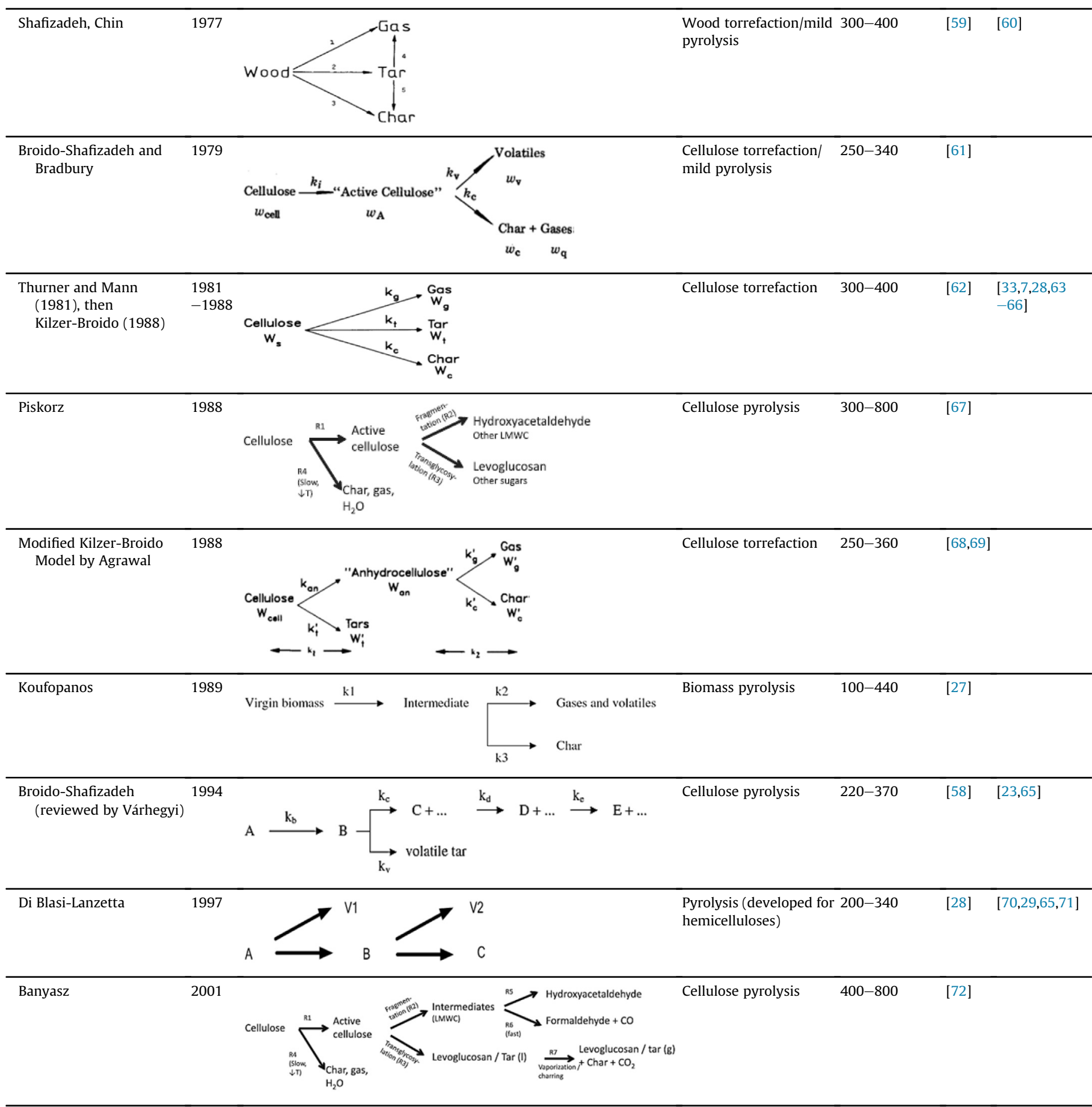


Table 1 (continued)

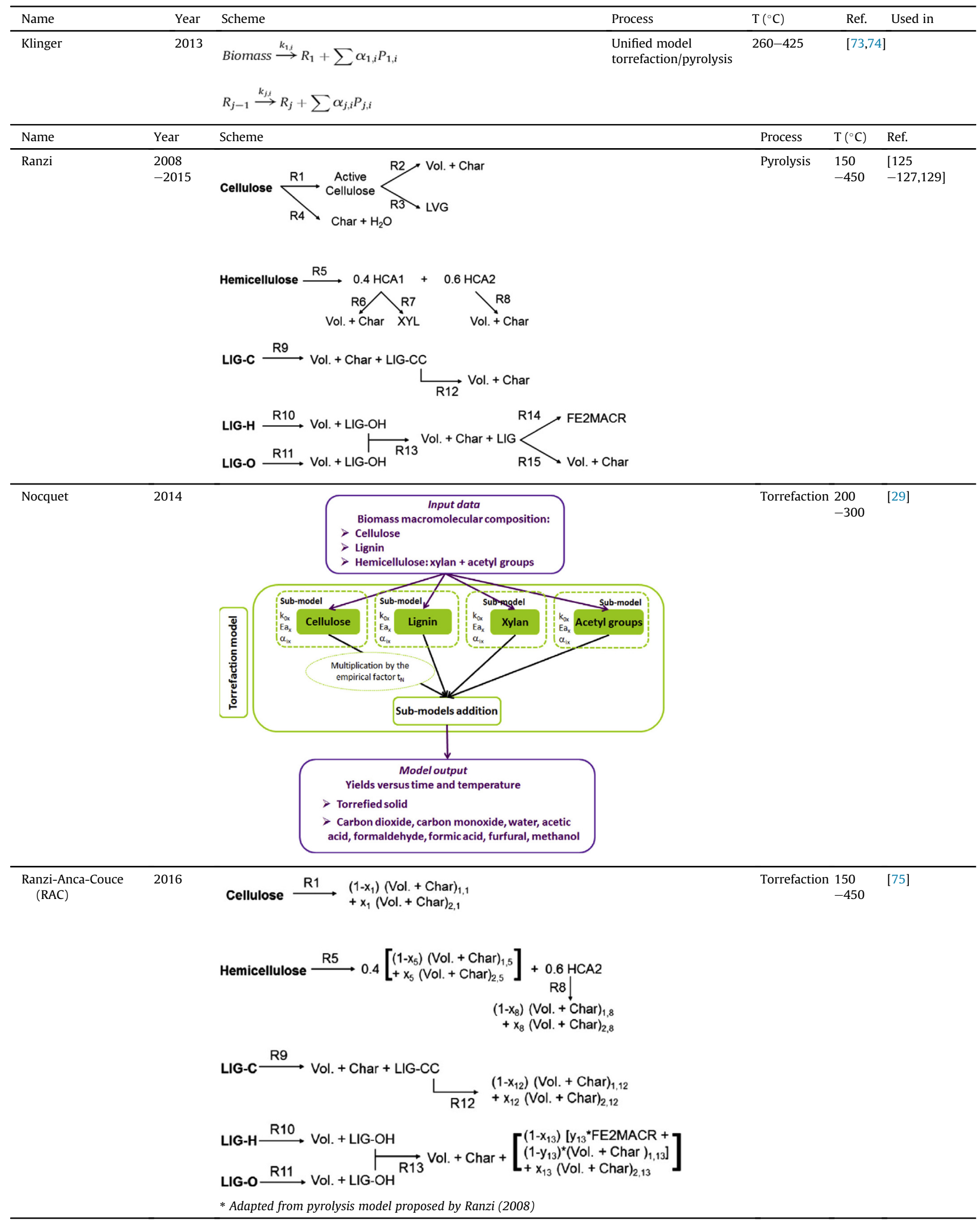


Table 1 (continued)

\begin{tabular}{|c|c|c|c|c|}
\hline Name & Year & Scheme & $\mathrm{T}\left({ }^{\circ} \mathrm{C}\right)$ & Ref. \\
\hline Dussan & 2017 & $\begin{array}{l}\text { Detailed model for hexose-based and pentose-based sugars in hemicelluloses pyrolysis (details Pyrolysis } \\
\text { in [52]) }\end{array}$ & $\begin{array}{l}150 \\
-450\end{array}$ & [52] \\
\hline Dussan & 2018 & $\begin{array}{l}\text { Detailed model for lignin pyrolysis based on } \beta-0-4^{\prime} \text { linked dimers of lignin base units (details in Pyrolysis } \\
\text { [53]) }\end{array}$ & $\begin{array}{l}150 \\
-450\end{array}$ & [53] \\
\hline
\end{tabular}

\subsection{Second-level model}

New assumptions were proposed in a second level of the torrefaction model to improve the representation of biomass behavior in torrefaction through a more accurate description of the macromolecular component behavior. This was achieved by:

replacing $\mathrm{C}^{\mathrm{II}}$ fraction kinetics by « cellulose $\mathrm{I»}\left(\mathrm{C}^{\mathrm{I}}\right)$ to preserve the allomorphic structure I of native cellulose in biomass;

Table 2

Biomass main macromolecular composition as considered for the modelling of the behavior of the five raw biomasses in torrefaction.

\begin{tabular}{llll}
\hline Macromolecular component & Cellulose & Hemicelluloses & Lignin \\
\hline \multicolumn{2}{l}{ Extracted fractions considered for the torrefaction model } & $\mathrm{H}_{1}$ & \\
1st level model & $\mathrm{Cl}^{\mathrm{II}}$ & $\mathrm{H}_{1}$ & $\mathrm{~L}$ \\
2nd level model & $\mathrm{C}^{\mathrm{I}}$ & $\mathrm{H}_{\mathrm{T}}$ & $\mathrm{L}$ \\
Raw biomass composition & $\% \mathrm{wmf}$ & & \\
Ash-wood & 43.7 & 24.9 & 31.4 \\
Beech & 44.3 & 27.2 & 28.4 \\
Miscanthus & 51.4 & 25.7 & 22.9 \\
Pine & 41.3 & 29.3 & 29.4 \\
Wheat straw & 45.8 & 29.1 & 25.0 \\
\hline
\end{tabular}

- weighting the hemicelluloses contribution by taking into account « hemicelluloses 1 » $\left(\mathrm{H}_{1}\right)$ and «hemicelluloses 2 » $\left(\mathrm{H}_{2}\right)$ in a new « total hemicelluloses » fraction $\left(\mathrm{H}_{\mathrm{T}}\right)$.

Consequently, and according to the extraction procedure, the proportions of $\mathrm{C}^{\mathrm{I}}$ and $\mathrm{H}_{1}$ fractions in the «DMSO residue » fraction (DMSOr) had to be estimated, as well as the ratio $\mathrm{H}_{1} / \mathrm{H}_{2}$ per biomass

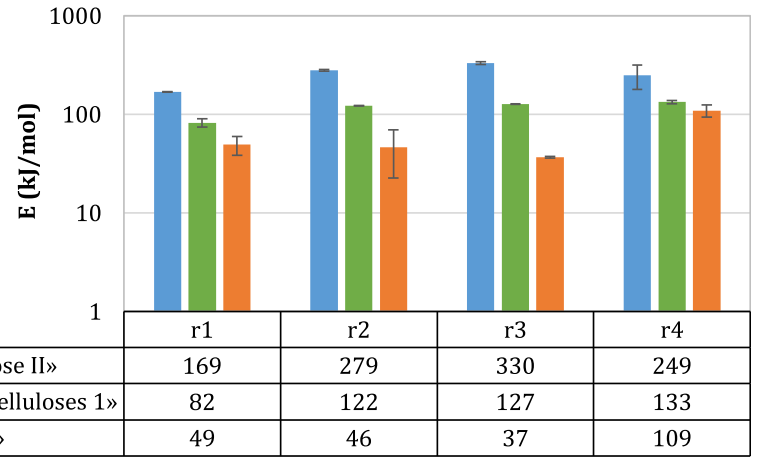

Fig. 1. Average activation energy $(\mathrm{kJ} / \mathrm{mol})$ per chemical reaction of $\mathrm{C}^{\mathrm{Il}}, \mathrm{H}_{1}$ and $\mathrm{L}$ fractions in torrefaction.

Table 3

Kinetic parameters of 2-succesive step kinetic model calculated for extracted fractions.

\begin{tabular}{|c|c|c|c|c|c|c|c|c|c|c|}
\hline \multicolumn{11}{|c|}{ «cellulose II» $\left(\mathrm{C}^{\mathrm{II}}\right)$} \\
\hline & \multicolumn{2}{|l|}{ ash-wood } & \multicolumn{2}{|l|}{ beech } & \multicolumn{2}{|l|}{ miscanthus } & \multicolumn{2}{|l|}{ pine } & \multicolumn{2}{|c|}{ wheat straw } \\
\hline & $\mathrm{k}_{0}\left(\mathrm{~s}^{-1}\right)$ & $\mathrm{E}(\mathrm{kJ} / \mathrm{mol})$ & $\mathrm{k}_{0}\left(\mathrm{~s}^{-1}\right)$ & $\mathrm{E}(\mathrm{kJ} / \mathrm{mol})$ & $\mathrm{k}_{0}\left(\mathrm{~s}^{-1}\right)$ & $\mathrm{E}(\mathrm{kJ} / \mathrm{mol})$ & $\mathrm{k}_{0}\left(\mathrm{~s}^{-1}\right)$ & $\mathrm{E}(\mathrm{kJ} / \mathrm{mol})$ & $\mathrm{k}_{0}\left(\mathrm{~s}^{-1}\right)$ & $\mathrm{E}(\mathrm{kJ} / \mathrm{mol})$ \\
\hline$r_{1}(A \rightarrow B)$ & $1.32 \cdot 10^{12}$ & 167 & $1.32 \cdot 10^{12}$ & 170 & $1.32 \cdot 10^{12}$ & 170 & $1.32 \cdot 10^{12}$ & 171 & $1.32 \cdot 10^{12}$ & 167 \\
\hline$r_{2}\left(A \rightarrow V_{1}\right)$ & $9.10 \cdot 10^{21}$ & 276 & $1.06 \cdot 10^{20}$ & 290 & $1.06 \cdot 10^{21}$ & 278 & $7.50 \cdot 10^{21}$ & 278 & $1.06 \cdot 10^{21}$ & 274 \\
\hline $\mathrm{r}_{3}(\mathrm{~B} \rightarrow \mathrm{C})$ & $9.30 \cdot 10^{30}$ & 331 & $2.10 \cdot 10^{30}$ & 331 & $2.10 \cdot 10^{30}$ & 327 & $9.30 \cdot 10^{30}$ & 348 & $2.10 \cdot 10^{30}$ & 312 \\
\hline$r_{4}\left(B \rightarrow V_{2}\right)$ & $3.09 \cdot 10^{18}$ & 333 & $3.09 \cdot 10^{18}$ & 197 & $3.09 \cdot 10^{18}$ & 195 & $3.09 \cdot 10^{18}$ & 333 & $3.09 \cdot 10^{18}$ & 185 \\
\hline Mean $\varepsilon_{\mathrm{a}}$ & $8.5 \cdot 10^{-4}$ & & $1.0 \cdot 10^{-4}$ & & $5.4 \cdot 10^{-5}$ & & $3.1 \cdot 10^{-4}$ & & $1.6 \cdot 10^{-4}$ & \\
\hline Mean $\varepsilon_{\mathrm{r}}$ & $0.120 \%$ & & $0.015 \%$ & & $0.008 \%$ & & $0.038 \%$ & & $0.026 \%$ & \\
\hline \multicolumn{11}{|c|}{ «hemicelluloses $1 »\left(\mathrm{H}_{1}\right)$} \\
\hline & \multicolumn{2}{|l|}{ ash-wood } & \multicolumn{2}{|l|}{ beech } & \multicolumn{2}{|l|}{ miscanthus } & \multicolumn{2}{|l|}{ pine } & \multicolumn{2}{|c|}{ wheat straw } \\
\hline & $\mathrm{k}_{0}\left(\mathrm{~s}^{-1}\right)$ & $\mathrm{E}(\mathrm{kJ} / \mathrm{mol})$ & $\mathrm{k}_{0}\left(\mathrm{~s}^{-1}\right)$ & $\bar{E}(\mathrm{~kJ} / \mathrm{mol})$ & $\mathrm{k}_{0}\left(\mathrm{~s}^{-1}\right)$ & $\mathrm{E}(\mathrm{kJ} / \mathrm{mol})$ & $\mathrm{k}_{0}\left(\mathrm{~s}^{-1}\right)$ & $\mathrm{E}(\mathrm{kJ} / \mathrm{mol})$ & $\mathrm{k}_{0}\left(\mathrm{~s}^{-1}\right)$ & $\overline{E(\mathrm{~kJ} / \mathrm{mol})}$ \\
\hline$r_{1}(A \rightarrow B)$ & $7.02 \cdot 10^{5}$ & 91 & $7.09 \cdot 10^{5}$ & 88 & $1.15 \cdot 10^{6}$ & 71 & $1.21 \cdot 10^{6}$ & 75 & $6.36 \cdot 10^{5}$ & 87 \\
\hline$r_{2}\left(A \rightarrow V_{1}\right)$ & $1.71 \cdot 10^{9}$ & 123 & $1.66 \cdot 10^{9}$ & 121 & $1.67 \cdot 10^{9}$ & 121 & $1.67 \cdot 10^{9}$ & 121 & $1.59 \cdot 10^{9}$ & 124 \\
\hline$r_{3}(B \rightarrow C)$ & $6.83 \cdot 10^{8}$ & 128 & $7.09 \cdot 10^{8}$ & 125 & $7.21 \cdot 10^{8}$ & 126 & $7.20 \cdot 10^{8}$ & 126 & $6.63 \cdot 10^{8}$ & 129 \\
\hline$r_{4}\left(B \rightarrow V_{2}\right)$ & $2.44 \cdot 10^{9}$ & 139 & $2.46 \cdot 10^{9}$ & 133 & $2.50 \cdot 10^{9}$ & 127 & $2.50 \cdot 10^{9}$ & 128 & $2.31 \cdot 10^{9}$ & 137 \\
\hline Mean $\varepsilon_{\mathrm{a}}$ & $3.1 \cdot 10^{-5}$ & & $4.4 \cdot 10^{-5}$ & & $2.7 \cdot 10^{-4}$ & & $1.5 \cdot 10^{-4}$ & & $2.8 \cdot 10^{-5}$ & \\
\hline Mean $\varepsilon_{\mathrm{r}}$ & $0.005 \%$ & & $0.025 \%$ & & $0.301 \%$ & & $0.123 \%$ & & $0.013 \%$ & \\
\hline \multicolumn{11}{|l|}{ «lignin» $(\mathrm{L})$} \\
\hline & \multicolumn{2}{|l|}{ ash-wood } & \multicolumn{2}{|l|}{ beech } & \multicolumn{2}{|l|}{ miscanthus } & \multicolumn{2}{|l|}{ pine } & \multicolumn{2}{|c|}{ wheat straw } \\
\hline & $\mathrm{k}_{0}\left(\mathrm{~s}^{-1}\right)$ & $\bar{E}(\mathrm{~kJ} / \mathrm{mol})$ & $\mathrm{k}_{0}\left(\mathrm{~s}^{-1}\right)$ & $\overline{E(\mathrm{~kJ} / \mathrm{mol})}$ & $\mathrm{k}_{0}\left(\mathrm{~s}^{-1}\right)$ & $\bar{E}(\mathrm{~kJ} / \mathrm{mol})$ & $\mathrm{k}_{0}\left(\mathrm{~s}^{-1}\right)$ & $\overline{E(\mathrm{~kJ} / \mathrm{mol})}$ & $\mathrm{k}_{0}\left(\mathrm{~s}^{-1}\right)$ & $\bar{E}(\mathrm{~kJ} / \mathrm{mol})$ \\
\hline$r_{1}(A \rightarrow B)$ & 78 & 54 & 7.2 & 43 & 259 & 54 & 211 & 63 & 0.8 & 32 \\
\hline$r_{2}\left(A \rightarrow V_{1}\right)$ & 33 & 54 & 35.3 & 54 & 861 & 65 & $1.67 \cdot 10^{-4}$ & 0.02 & 113 & 58 \\
\hline$r_{3}(B \rightarrow C)$ & 21 & 36 & 5 & 36 & 2.2 & 38 & 32 & 36 & 0.1 & 37 \\
\hline$r_{4}\left(B \rightarrow V_{2}\right)$ & $3.38 \cdot 10^{4}$ & 111 & $3.06 \cdot 10^{4}$ & 131 & $3.42 \cdot 10^{4}$ & 90 & $3.39 \cdot 10^{4}$ & 93 & $2.01 \cdot 10^{4}$ & 120 \\
\hline Mean $\varepsilon_{\mathrm{a}}$ & $1.1 \cdot 10^{-5}$ & & $<1.0 \cdot 10^{-5}$ & & $<1.0 \cdot 10^{-5}$ & & $1.1 \cdot 10^{-4}$ & & $<1.0 \cdot 10^{-5}$ & \\
\hline Mean $\varepsilon_{\mathrm{r}}$ & $0.001 \%$ & & $<0.001 \%$ & & $<0.001 \%$ & & $0.019 \%$ & & $0.002 \%$ & \\
\hline
\end{tabular}




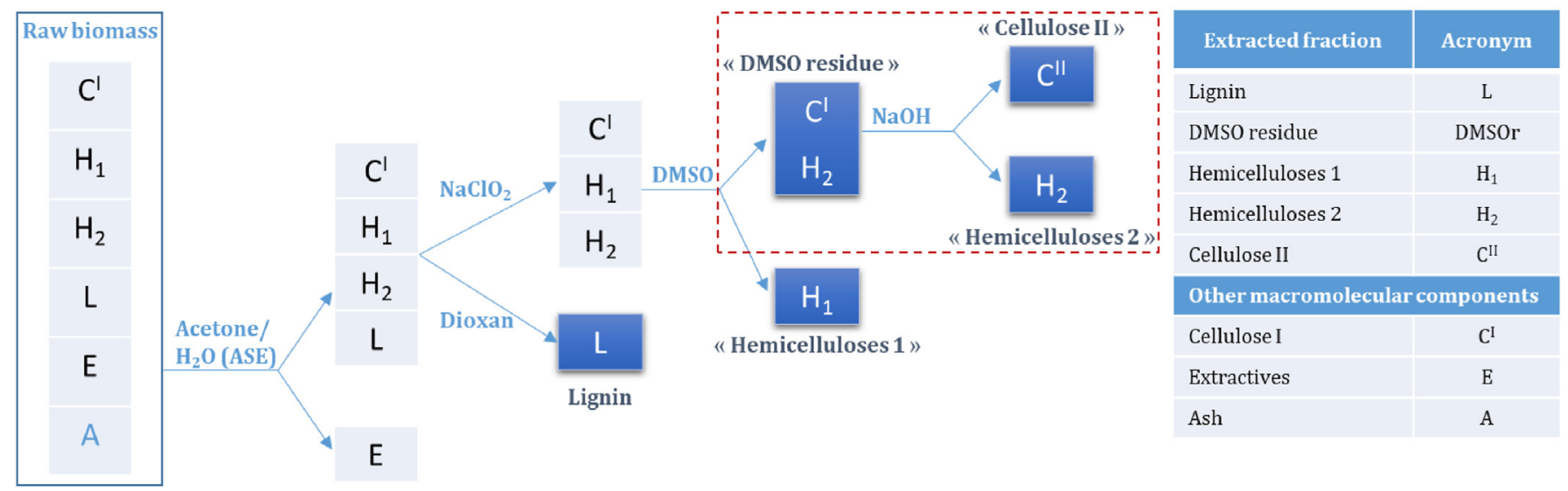

Fig. 2. Extraction procedure sub-system for the sugar mass balance of the DMSOr fraction (dashed line).

(see Fig. 2 and part 1). This was performed thanks to sugar mass balances carried out on the extracted fractions composed of polysaccharides.

\subsubsection{Sugar mass balances}

2.2.1.1. Composition of the DMSOr fraction. By considering the extraction procedure scheme, a sub-system including «DMSO residue» (DMSOr), $\mathrm{C}^{\mathrm{II}}$ and $\mathrm{H}_{2}$ fractions was defined (Fig. 2). Sugar mass balances were based on the composition of major sugars for each fraction, namely glucose and xylose [76]. The higher uncertainty in the determination of minor sugars, namely mannose, arabinose and galactose, justified their discard. Furthermore, acetyl group content was not considered as they are partially destroyed due to the alkaline treatment.

In a mass-fraction basis, DMSOr fraction composition per biomass corresponded to:

$$
1=x_{C^{I I}, \mathrm{DMSO}_{r}}+x_{\mathrm{H}_{2}, \mathrm{DMSO}_{r}}
$$

Considering sugar composition of each fraction (Part 1, Table 1) and for an individual sugar (glucose, Glu, or xylose, Xyl) in DMSOr fraction, sugar mass balance of this fraction was:

$x_{\text {Glu }, \text { DMSO }_{r}}=x_{G l u, C^{I I}} x_{C^{I I}, \mathrm{DMSO}_{r}}+x_{G l u, \mathrm{H}_{2}} x_{\mathrm{H}_{2}, \mathrm{DMSO}_{r}}$

\section{Table 4}

Composition of the DMSOr fraction in $\mathrm{C}^{\mathrm{l}}$ and $\mathrm{H}_{2}$ fractions calculated by glucose and xylose sugar mass balances.

\begin{tabular}{|c|c|c|c|c|c|}
\hline \multirow[b]{3}{*}{ Monosugar } & \multicolumn{5}{|c|}{$C^{\mathrm{I}}$ mass fraction in DMSOr fraction $\left(x_{C^{\prime}, D M S O_{r}}=x_{C^{I l}, D M S O_{r}}\right)$} \\
\hline & Ash-wood & Beech & Miscanthus & Pine & Wheat straw \\
\hline & \multicolumn{5}{|l|}{ \%wmf } \\
\hline Glucose (Glu) & 74.4 & 75.3 & 74.1 & 78.0 & 76.1 \\
\hline Xylose (Xyl) & 80.3 & 79.7 & 86.2 & 79.8 & 88.4 \\
\hline Average & 77.3 & 77.5 & 80.1 & 78.9 & 82.3 \\
\hline Absolute error $\left(\varepsilon_{a}\right)$ & 5.9 & 4.4 & 12.1 & 1.8 & 12.3 \\
\hline \multirow[t]{3}{*}{ Relative error $\left(\varepsilon_{r}\right)$} & $8.1 \%$ & $5.9 \%$ & $16.4 \%$ & $2.3 \%$ & $16.1 \%$ \\
\hline & \multicolumn{5}{|c|}{$\mathrm{H}_{2}$ mass fraction in DMSOr fraction $\left(x_{\mathrm{H}_{2}, D_{M S O}}\right)$} \\
\hline & Ash-wood & Beech & Miscanthus & Pine & Wheat straw \\
\hline Monosugar & \multicolumn{5}{|l|}{ \%wmf } \\
\hline Glucose (Glu) & 25.6 & 24.7 & 25.9 & 22.0 & 23.9 \\
\hline Xylose (Xyl) & 19.7 & 20.3 & 13.8 & 20.2 & 11.6 \\
\hline Average & 22.7 & 22.5 & 19.9 & 21.1 & 17.7 \\
\hline Absolute error $\left(\varepsilon_{a}\right)$ & 5.9 & 4.4 & 12.1 & 1.8 & 12.3 \\
\hline Relative error $\left(\varepsilon_{r}\right)$ & $23.3 \%$ & $18.1 \%$ & $46.9 \%$ & $8.0 \%$ & $51.4 \%$ \\
\hline
\end{tabular}

$\mathrm{C}^{\mathrm{I}}$ and $\mathrm{C}^{\mathrm{II}}$ fractions differed in structure arrangement, which affected the allomorphic structure (I or II). However, they are equivalent in terms of mass percentage in DMSOr and sugar composition:

$x_{C^{I}, D M S O}=x_{C^{I I}, D M S O}$

By combining Eqs. (7)-(9), $x_{C^{l}, D M S O}$ and $x_{H_{2}, \text { DMSO }}$ could be calculated as:

$x_{C^{I}, \mathrm{DMSO}_{r}}=x_{\mathrm{Cl}^{I I}, \mathrm{DMSO} \mathrm{O}_{r}}=\frac{x_{G l u, D M S O}-x_{G l u, H_{2}}}{x_{G l u, C^{I I}}-x_{G l u, H_{2}}}$

$x_{\mathrm{H}_{2}, \mathrm{DMSO}_{r}}=1-x_{C^{I}, \mathrm{DMSO}_{r}}$

DMSOr fraction composition in $\mathrm{C}^{\mathrm{l}}$ and $\mathrm{H}_{2}$ fractions per biomass was calculated through Eqs. (10) and (11), by considering the sugar content on glucose or xylose (Part 1, Table 1). The average of both results per biomass was indicated and the relative error between them was calculated (Table 4). It is noteworthy that a considerable error rate was expected, due to the difficulties to obtain an accurate sugar composition determination.

The most significant difference in the DMSOr composition estimated from glucose and xylose was obtained for miscanthus and wheat straw. This behavior is in agreement with the higher heterogeneity of agricultural biomasses, which leads to a higher uncertainty in their sugar composition determination. Indeed, the measurement was carried out as follows: firstly, the total polysaccharide content was determined for each biomass; then, the distinction was made between cellulose composition, only based on glucose sugar, and hemicelluloses composition, composed of glucose and other sugars. The distribution of the glucose content between cellulose and hemicelluloses was based on typical ratios of mannose/glucose reported in the literature (typically, they correspond to 1.6 for deciduous wood and to 1.0 for coniferous wood) $[77,78]$. As the sugar distribution of agricultural biomasses and herbaceous crop hemicelluloses is relatively poorly known, the 1.0 ratio was supposed. Furthermore, a higher error was associated to the determination of minor sugars. Despite these uncertainties, the composition of the DMSOr fraction was around $80 \% \mathrm{C}^{\mathrm{I}}$ and $20 \% \mathrm{H}_{2}$ for the five biomasses.

2.2.1.2. Composition of total hemicelluloses. The composition of $\mathrm{H}_{1}$ and $\mathrm{H}_{2}$ fractions in total hemicelluloses $\left(\mathrm{H}_{\mathrm{T}}\right)$ in biomass needed to be determined. To do this, the presence of glucose in all polysaccharide fractions would suggest to make a global polysaccharide 
balance, including all cellulose- and hemicellulose-based fractions. However, the results of this global balance would be strongly impacted by the uncertainty in sugar composition determination. A second option is to follow a similar procedure to that previously presented for determining DMSOr composition because all cellulose from raw biomass was preserved in this fraction.

Cellulose and hemicelluloses mass fractions for each biomass were firstly estimated from raw biomass composition, reported in Ref. [76]. Then, DMSOr mass fraction in raw biomass was calculated:

$x_{\mathrm{DMSO}_{r}, r b}=\frac{x_{C, r b}}{x_{C^{I I}, D M S O_{r}}}$

$\mathrm{H}_{2}$ mass fraction in raw biomass was estimated by difference:

$x_{H_{2}, r b}=x_{D M S O_{r}, r b}-x_{C, r b}$

$\mathrm{H}_{1}$ mass fraction could be derived as follows:

$x_{H_{1}, r b}=x_{H_{T}, r b}-x_{H_{2}, r b}$

The hemicelluloses composition in terms of $\mathrm{H}_{1}$ and $\mathrm{H}_{2}$ mass fractions was then calculated (Table 5):

$x_{H_{1}, H_{T}}=\frac{x_{H_{1}, r b}}{x_{H_{1}, r b}+x_{H_{2}, r b}}$

$x_{H_{2}, H_{T}}=\frac{x_{H_{2}, r b}}{x_{H_{1}, r b}+x_{H_{2}, r b}}$

These results revealed that none of the hemicellulose fractions was negligible, which was coherent with their different sugar composition. Subsequently, it could be stated that $\mathrm{H}_{1}$ and $\mathrm{H}_{2}$ are complementary fractions to describe hemicelluloses in biomass.

The calculated proportions of $\mathrm{H}_{1}$ and $\mathrm{H}_{2}$ fractions in raw biomass (Table 5) were checked by recalculating raw biomass glucose content (Eq. (17)) and by comparing the obtained values to those experimentally measured (Table 6). The relative error between measured and calculated values for glucose was around $15.0 \% \mathrm{wmf}$, with the higher values again for agricultural biomasses. The uncertainty in sugar content determination led to consider this relative error as low and thus to accept the estimated total hemicelluloses composition.

$x_{G l u, r b}=x_{G l u, H_{1}} x_{H_{1}, r b}+x_{G l u, H_{2}} x_{H_{2}, r b}+x_{G l u, C} x_{C, r b}$

To sum up, hemicelluloses composition determination was validated by the sugar mass balances, with the limitations of the uncertainty associated to the sugar content determination. By considering both $\mathrm{H}_{1}$ and $\mathrm{H}_{2}$ fractions per raw biomass, hemicelluloses representation is expected to be completed. The obtained results justified that these two fractions need to be considered in the total hemicellulose description, at least in terms of solid kinetics.

\subsubsection{Reconstruction of the complementary fractions}

2.2.2.1. «Cellulose $I »\left(C^{\mathrm{I}}\right)$. «Cellulose $\mathrm{I}$ ( $\left(\mathrm{C}^{\mathrm{I}}\right)$ behavior in torrefaction was reconstructed by considering the composition of DMSOr fraction:

$$
\begin{gathered}
m_{\text {DMSO }_{r}}\left(t_{i}, T_{i}\right)=x_{C^{I}, D^{\prime} S_{r}} m_{C^{I}}\left(t_{i}, T_{i}\right)+x_{H_{2}, D_{M S O}} m_{H_{2}}\left(t_{i}, T_{i}\right) \\
T_{i} \in[200,300]^{\circ} \mathrm{C}
\end{gathered}
$$

$\mathrm{C}^{\mathrm{I}}$ and $\mathrm{C}^{\mathrm{II}}$ fractions behavior in torrefaction were compared (Fig. 3. The reconstructed curves, including interactions, were directly implemented in the second-level model. The relative error between remaining solid mass estimated through $C^{\mathrm{I}}$ fractions and the experimental behavior of $\mathrm{C}^{\mathrm{II}}$ fractions in TGA-GC/MS was calculated and represented in the Supplementary Material (Figure S5).

2.2.2.2. «Total hemicelluloses» $\left(H_{T}\right)$. «Total hemicelluloses» $\left(\mathrm{H}_{\mathrm{T}}\right)$ fraction behavior in torrefaction was reconstructed for each biomass through a weighted sum of the contributions of the kinetic behavior of $\mathrm{H}_{1}$ and $\mathrm{H}_{2}$ fractions according to their proportions per biomass (Table 5). The $\mathrm{H}_{\mathrm{T}}$ fraction remaining solid mass at a given time and temperature was:

$$
\begin{gathered}
m_{H_{T}}\left(t_{i}, T_{i}\right)=x_{H_{1}, H_{T}} m_{H_{1}}\left(t_{i}, T_{i}\right)+x_{H_{2}, H_{T}} m_{H_{2}}\left(t_{i}, T_{i}\right) \\
T_{i} \in[200,300]^{\circ} \mathrm{C}
\end{gathered}
$$

The $\mathrm{H}_{\mathrm{T}}$ fraction behavior in torrefaction was reconstructed for each raw biomass (Fig. 4).

The main difference in the behavior of both hemicellulose fractions was found in the dynamic step, which corresponds to the major degradation of this fraction and whose extent depended on sugar composition. Solid mass loss was faster for all $\mathrm{H}_{1}$ fractions except for that of pine. This can be explained by its higher composition in mannose, whose degradation is slower than that of xylose, which is the major sugar of the other $\mathrm{H}_{1}$ fractions. The slower degradation of wheat straw $\mathrm{H}_{2}$ fractions compared to $\mathrm{H}_{1}$ fractions would be due to the considerable mannose content of this fraction. Then, the behavior of both hemicellulose fractions for all biomasses was nearly equivalent in the isothermal step, except in the case of the wheat straw $\mathrm{H}_{2}$ fraction, also presumably due to its high mannose content.

\subsubsection{Representation of the model}

The reconstructed fractions $\mathrm{C}^{\mathrm{I}}$ and $\mathrm{H}_{\mathrm{T}}$ were integrated in the additive model so as to improve biomass behavior representation. The proportions of cellulose $\left(\mathrm{C}^{\mathrm{l}}\right)$, hemicelluloses $\left(\mathrm{H}_{\mathrm{T}}\right)$ and lignin $(\mathrm{L})$ for this second-level of the model were indicated in Table 2. Accordingly, the model resulted in:

$$
\begin{aligned}
m_{r b}^{\prime}\left(t_{i}, T_{i}\right)= & x_{C, r b} m_{C^{I}}\left(t_{i}, T_{i}\right)+x_{H_{T}, r b} m_{H_{T}}\left(t_{i}, T_{i}\right)+x_{L, r b} m_{L}\left(t_{i}, T_{i}\right) \\
& T_{i} \in[200,300]^{\circ} \mathrm{C}
\end{aligned}
$$

\begin{tabular}{|c|c|c|c|c|c|}
\hline & \multicolumn{5}{|c|}{ total « hemicelluloses» $\left(\mathrm{H}_{\mathrm{T}}\right)$ fraction composition } \\
\hline & Ash-wood & Beech & Miscanthus & Pine & Wheat straw \\
\hline & $\% \mathrm{wmf}$ & & & & \\
\hline «hemicelluloses $1 »\left(\mathrm{H}_{1}\right), \mathrm{x}\left(\mathrm{H}_{1}, \mathrm{H}_{\mathrm{T}}\right)$ & 47.4 & 34.9 & 53.5 & 33.9 & 47.4 \\
\hline «hemicelluloses $2 »\left(\mathrm{H}_{2}\right), \mathrm{x}\left(\mathrm{H}_{2}, \mathrm{H}_{\mathrm{T}}\right)$ & 52.6 & 65.1 & 46.5 & 66.1 & 52.6 \\
\hline
\end{tabular}

As for the first-level model, the structure of the 2-successivestep kinetic model of Di Blasi and Lanzetta was selected. Kinetic

Table 5

Composition of total hemicelluloses in raw biomass related to the two hemicellulose extracted fractions $\left(\mathrm{H}_{1}\right.$ and $\left.\mathrm{H}_{2}\right)$. 
Table 6

Total glucose in raw biomass estimated by the composition of the extracted fractions.

\begin{tabular}{|c|c|c|c|c|c|}
\hline & \multicolumn{5}{|c|}{ Glucose, $x_{G l u, r b}$} \\
\hline & Ash-wood & Beech & Miscanthus & Pine & Wheat straw \\
\hline & \multicolumn{5}{|l|}{$\% w m f$} \\
\hline Calculated Sugar mass balances & 39.7 & 44.7 & 40.4 & 47.4 & 41.0 \\
\hline Measured Reported in [76] & 38.6 & 39.5 & 42.9 & 46.9 & 35.8 \\
\hline Absolute error $\left(\varepsilon_{a}\right)$ & 1.1 & 5.2 & 2.5 & 0.5 & 5.2 \\
\hline Relative error $\left(\varepsilon_{r}\right)$ & $2.7 \%$ & $13.2 \%$ & $5.7 \%$ & $1.1 \%$ & $14.3 \%$ \\
\hline
\end{tabular}
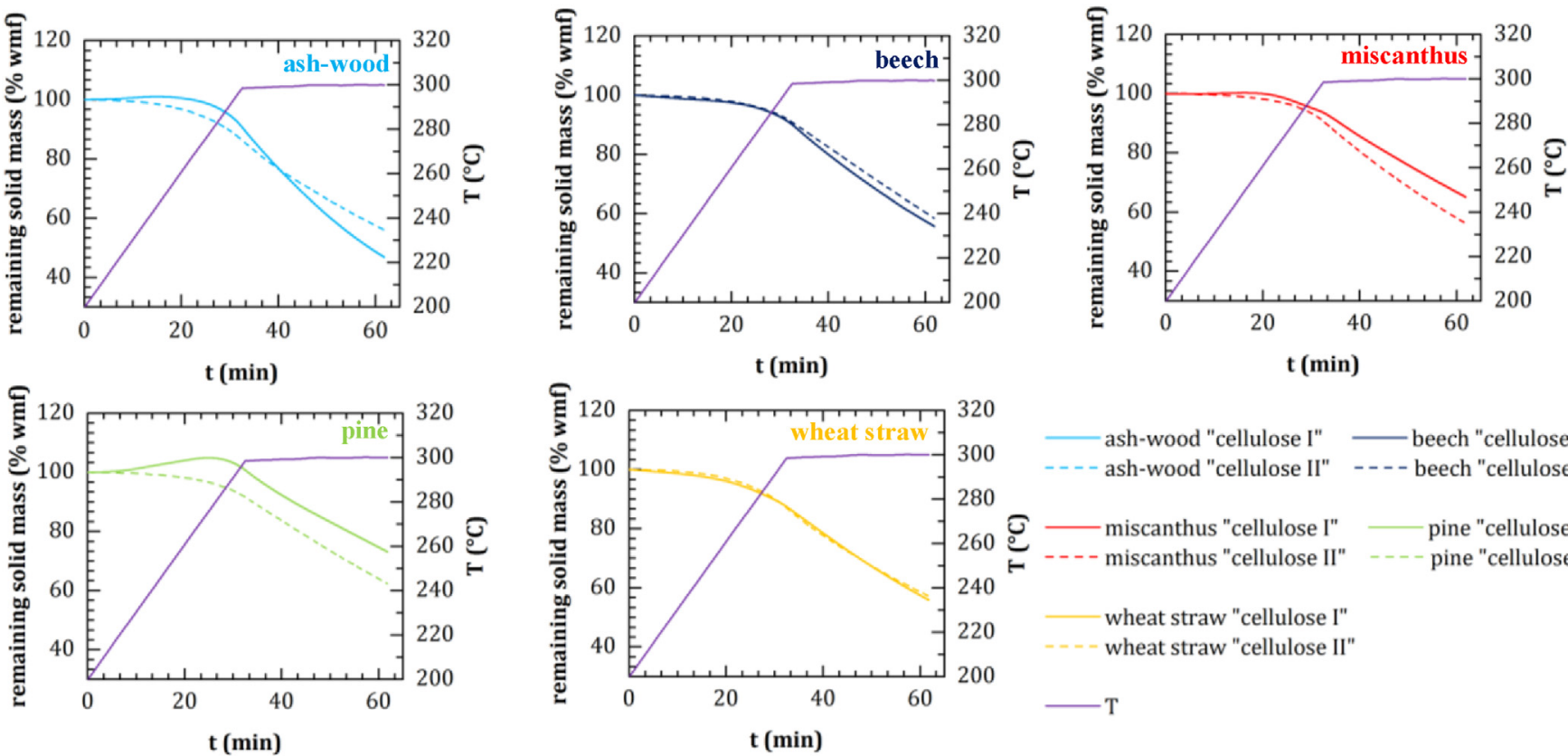

- ash-wood "cellulose I" — beech "cellulose I" _. - - ash-wood "cellulose II" _ - - - beech "cellulose II"

miscanthus "cellulose I" — pine "cellulose I" - - - miscanthus "cellulose II" - - - pine "cellulose II"

Fig. 3. Remaining solid mass in function of temperature and time of $C^{\mathrm{Il}}$ fractions and of the reconstructed $\mathrm{C}^{\mathrm{I}}$ fraction in torrefaction in TGA-GC/MS.
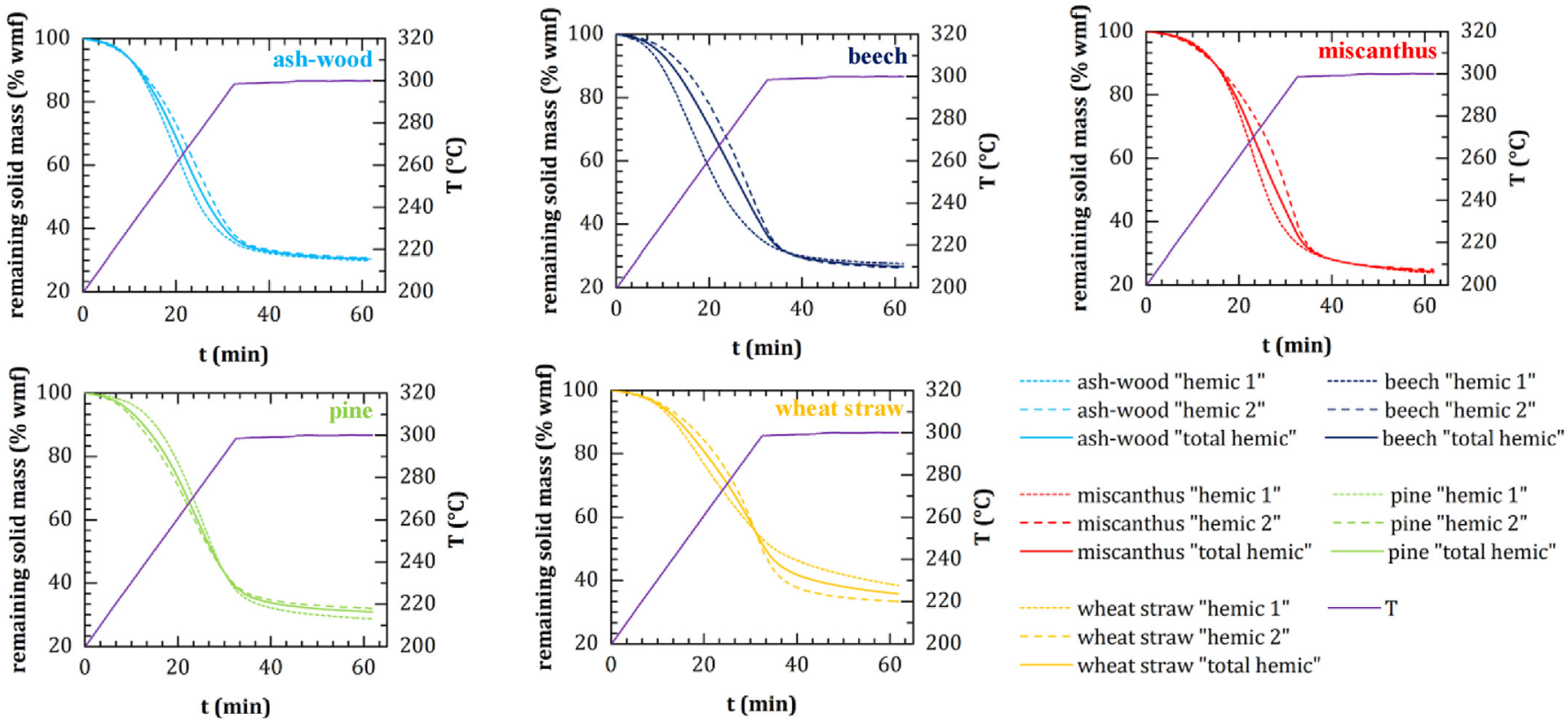

Fig. 4. Remaining solid mass in function of temperature and time of hemicellulose fractions $\left(\mathrm{H}_{1}, \mathrm{H}_{2}\right)$ and of the reconstructed $\mathrm{H}_{\mathrm{T}}$ fractions in torrefaction in TGA-GC/MS. 
Table 7

Kinetic parameters of the 2-succesive step kinetic model calculated for $\mathrm{H}_{\mathrm{T}}$ fractions.

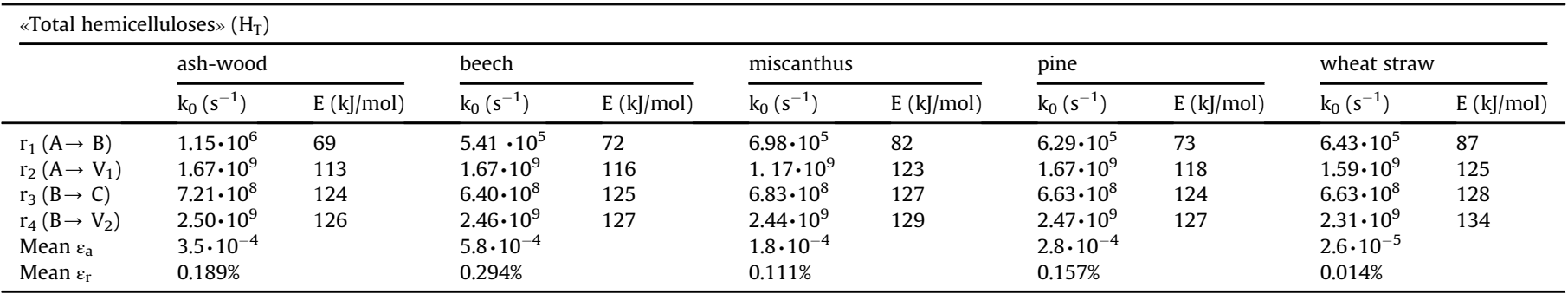
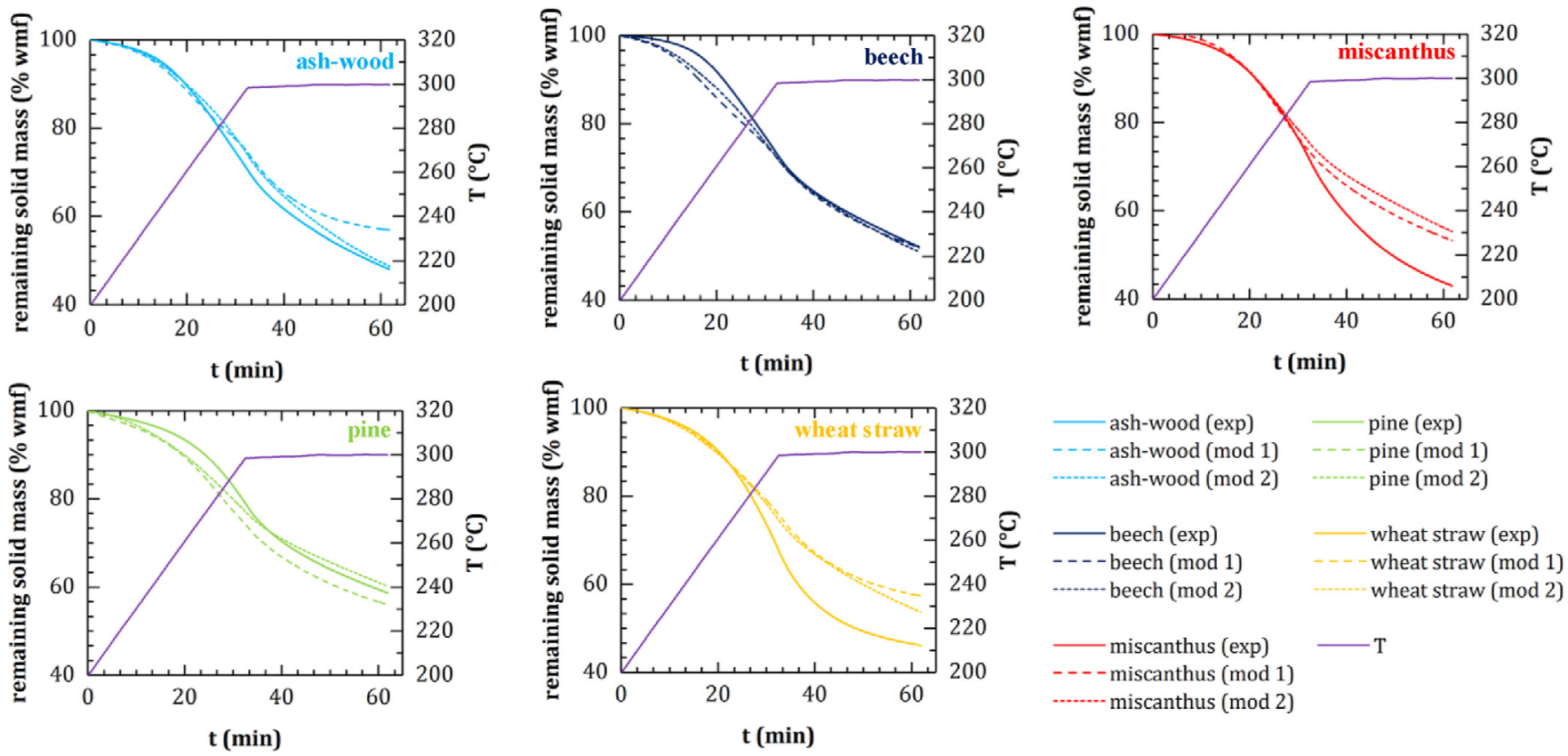

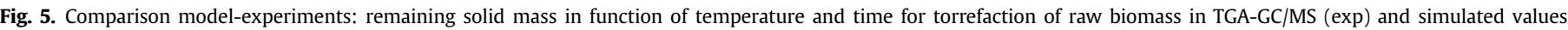
obtained through first-level model $(\bmod 1)$ and second-level model $(\bmod 2)$.

parameters were recalculated for $\mathrm{H}_{\mathrm{T}}$ (Table 7), while they were kept unchanged for $\mathrm{L}$ and $\mathrm{C}^{\mathrm{I}}$ fractions. The estimated behavior of $\mathrm{C}^{\mathrm{I}}$ fraction could not be adjusted to the Di Blasi-Lanzetta model structure. As a result, the calculated parameters for $\mathrm{Cl}^{\mathrm{II}}$ fractions were considered, due to the similar behavior of both fractions and their limited degradation in torrefaction (Fig. 3).

The pre-exponential factor of the first reaction $\left(\mathrm{A} \rightarrow \mathrm{B}, \mathrm{k}_{0,1}\right)$ was the main difference observed between the kinetic parameters calculated for the $\mathrm{H}_{T}$ and $\mathrm{H}_{1}$ fractions. The relative error in the parameters determination was higher for $\mathrm{H}_{\mathrm{T}}$ fractions from deciduous wood, while a lower error was found for miscanthus $\mathrm{H}_{T}$ fraction. The different sugar composition and kinetic behavior in torrefaction indicate that both hemicellulose fractions are complementary to represent hemicellulose behavior in torrefaction.

\section{Results and discussion}

\subsection{Model performances}

The modelled behaviors of each biomass with the first- and second-level model in torrefaction were compared to the experimental results (Fig. 5). The relative error between remaining solid mass estimated through first- and second-level models was compared to that experimentally obtained for raw biomass in TGAGC/MS in the Supplementary Material (Figure S6). This approach is based on the hypothesis that the initial macromolecular composition of biomass corresponds to the ratio between the extracted fractions, which allows to reconstruct raw biomass transformation through torrefaction. This implies that:

- Extraction procedure was supposed not to modify the macrocomponents in the raw material and to give a good representation of the fractions from raw biomass.

- According to the first-level model assumptions, $\mathrm{C}^{\mathrm{II}}, \mathrm{H}_{1}$ and $\mathrm{L}$ extracted fractions were identified to be representative of cellulose, hemicelluloses and lignin in biomass, respectively.

- According to the second-level model assumptions, $\mathrm{C}^{\mathrm{I}}, \mathrm{H}_{\mathrm{T}}$ and $\mathrm{L}$ extracted fractions were supposed to be representative of cellulose, hemicelluloses and lignin in biomass, respectively. Kinetics of hemicelluloses were changed by using $\mathrm{H}_{\mathrm{T}}$ in this case, while cellulose kinetics were kept unchanged.

- Extractives were supposed to be released below $200{ }^{\circ} \mathrm{C}$, so they did not participate in biomass torrefaction.

- Inorganic elements were supposed to be inert in the torrefaction temperature range. 
Model prediction is obviously dependent on the operating conditions and on biomass type. First-level model showed an accurate remaining solid mass prediction in the non-isothermal step until $33.3 \mathrm{~min}$ for ash-wood, miscanthus and wheat straw. In the case of pine, a constant deviation of $5 \%$ of the modelled curve compared to the experimental results was found from intermediate temperatures to the end of the isothermal step. An overestimation of the remaining solid mass for miscanthus and wheat straw was observed along the isothermal step. The observed deviation in the model predictions was not identical for biomasses from the same family, such as ash-wood and beech.

The second-level model lead to a more accurate description of the behavior of all biomass samples in the non-isothermal torrefaction. Thus, the underestimation of the remaining solid mass by the first-level model in this step was slightly improved for beech and significantly for pine. Furthermore, the prediction of the model in the isothermal step was also improved for ash-wood and pine. This better fitting of the second-level model may be explained by the fractions considered on its construction. As hemicelluloses are mostly degraded in the torrefaction temperature range, the consideration of $\mathrm{H}_{\mathrm{T}}$ fractions may lead to a more accurate description of their behavior. The second-level model leads to accurate predictions for woody biomass. However, only few changes in the prediction were observed for wheat straw and miscanthus in the two levels of the model. Deviations are mainly present in the isothermal region for these non-woody biomasses. This might correspond to the fact that their structure is poorly known, which leads to a higher uncertainty in their macromolecular and sugar characterization and, consequently, in their modelling [78,79]. Furthermore, the structure of agricultural biomasses may be more labile face to the thermal degradation, which may lead to an easier degradable structure at high torrefaction temperatures. Another hypothesis for explaining the deviation of the torrefaction model for agricultural biomasses and herbaceous crops at $300{ }^{\circ} \mathrm{C}$ could be that the extractives and ash content play a role on this prediction, at least at $300{ }^{\circ} \mathrm{C}$. In this sense, a similar high extractives content was measured for ash-wood (10.0\%wmf), miscanthus (8.6\%wmf) and pine (8.4\%wmf) [76]; however, a different deviation of the model was observed for these species. The same observation was found for the ash content, as miscanthus presented a similar ash content to that of ash-wood, around $2.8 \% \mathrm{wmf}$, while wheat straw ash content was much higher, $8.3 \%$ wmf. According to these results, the relationship between the consideration of extractives and ash content in the torrefaction model and the accuracy of its prediction would be non-trivial.

\subsection{Analysis of the extracted fraction behaviour}

The results of the torrefaction additive model were compared to the experimental data obtained with the raw biomass and the extracted fractions. The comparison of the degradation rate profiles was presented for a better identification of the differences between the solid kinetic profiles (Fig. 6).

The first maximum in the degradation rate profiles of the mixtures corresponded to the behavior of the $\mathrm{H}_{1}$ fractions, except for pine. The temperature of this maximum of degradation rate was in agreement with those obtained for $\mathrm{H}_{1}$ fractions. The second maximum, close to $300{ }^{\circ} \mathrm{C}$, principally corresponded to the behavior of the $\mathrm{C}^{\mathrm{II}}$ fraction. Cellulose is mostly degraded at temperatures close to and above $300^{\circ} \mathrm{C}$, so in this case its degradation was interrupted at $300^{\circ} \mathrm{C}$. The impact of lignin degradation on both maxima was low, as it is only slightly and progressively degraded in this temperature range (the maximum degradation rates measured for the extracted fraction were around $1.0 \% \mathrm{wmf} \mathrm{min}^{-1}$ ). These maxima in the degradation rate profiles were reproduced in the additive model behavior.

These results show that the first stage (non-isotherm) is dominated by hemicellulose decomposition, while the second (isotherm) is dominated by cellulose decomposition. The bigger deviations are present in the second stage for non-woody biomass, with commonly a higher content of extractives or inorganics which could explain these differences. Extractives could be as well released in this temperature range [48], although their main release is commonly at lower temperatures or even higher temperatures. Regarding inorganics, they could mainly catalyze cellulose decomposition, which is not detected in the kinetics of $\mathrm{Cl}^{\mathrm{II}}$ or $\mathrm{C}^{\mathrm{I}}$ cellulose due the samples are previously leached. It was shown in literature that during pyrolysis, when the content of inorganics was decreased through leaching or increased through doping, the position of the shoulder peak related to hemicellulose decomposition is barely affected, while the peak related to cellulose and specially the tail related to lignin take place at lower temperatures with a higher inorganic content [80].

The kinetics derived for beech wood components were also employed to describe torrefaction of the other biomasses (ashwood, pine, miscanthus and wheat straw). The results, which were presented in the Supplementary Material, Figure S7, showed that the use of the kinetics derived from each component led to generally better results, especially in the first stage (nonisothermal) of miscanthus and straw, and to a lower extent for pine. The differences for ash-wood predictions using beech kinetics are the lowest, which can be justified as both are hardwood species. Differences between predictions and experiments are still present mainly in the second stage (isothermal) of miscanthus and wheat straw, and to a lower extent for pine during the whole conversion.

\subsection{Comparison to other models in the literature}

The prediction of biomass behavior in torrefaction by the proposed additive model based on extracted fractions was compared to previous torrefaction models in the literature by Nocquet [29] and Ranzi-Anca-Couce [51] (Fig. 7). In the first case, Nocquet's model was applied for each raw biomass by taking into account its composition on cellulose, hemicelluloses and lignin. The difference between the Nocquet model and the proposed additive model in this work is that the one of Nocquet is based on commercial compounds. In the second case, the Ranzi-Anca-Couce (RAC) model with the proposed biomass composition for softwood in Refs. [51] was applied to pine, while that for hardwood was considered for the other biomass samples, including agricultural and herbaceous crops. The adjustable parameter of this model, representing the amount of the initial fragmentation primary products, was considered to be of 0.2 as in Ref. [51] for representing TGA conditions. This value supposes a limited charring, despite the low heating rates and temperatures, due to the low initial masses in TGA experiments.

The benefits of considering extracted macromolecular components instead of commercial ones were revealed through the comparison to the Nocquet's model. In the proposed new model the specific composition of hemicelluloses, cellulose and lignin could be considered, while in the case of the Nocquet's model these components were described through commercial xylan, Avicel cellulose and dioxan lignin, respectively. The prediction of the Nocquet's model in the isothermal step was slightly better for miscanthus and wheat straw in terms of absolute value of the remaining solid mass. However, the modelled profile of remaining solid mass was different to that of the experimental results, while the proposed novel torrefaction model appeared to better fit them. The predictions of Nocquet generally lead to a significantly slower conversion in the first stage (non-isothermal) and a faster 

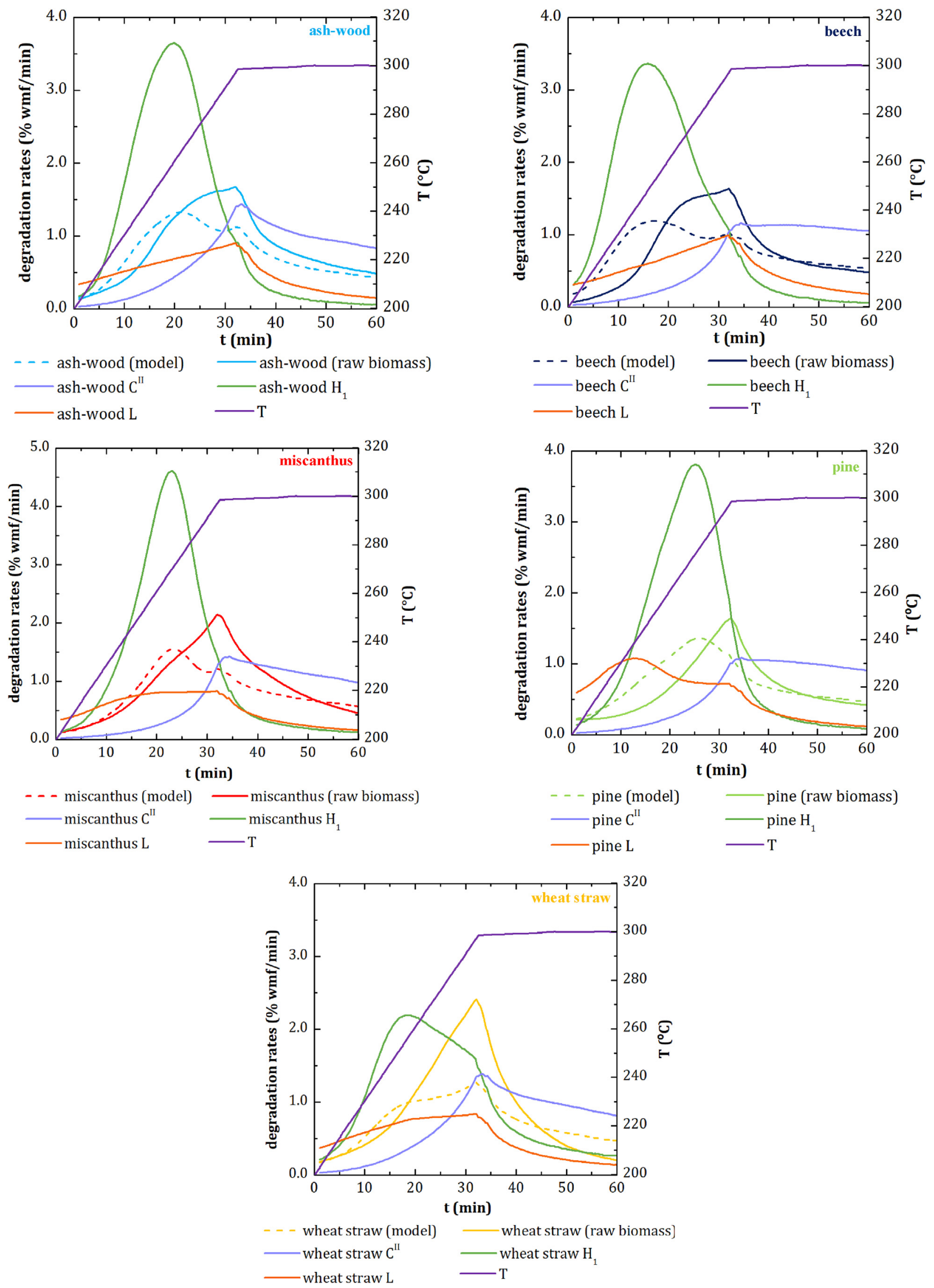

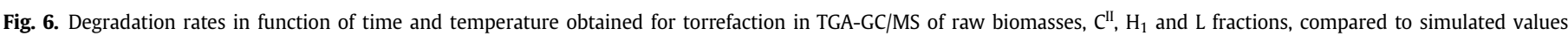
obtained with the first-level torrefaction model. 

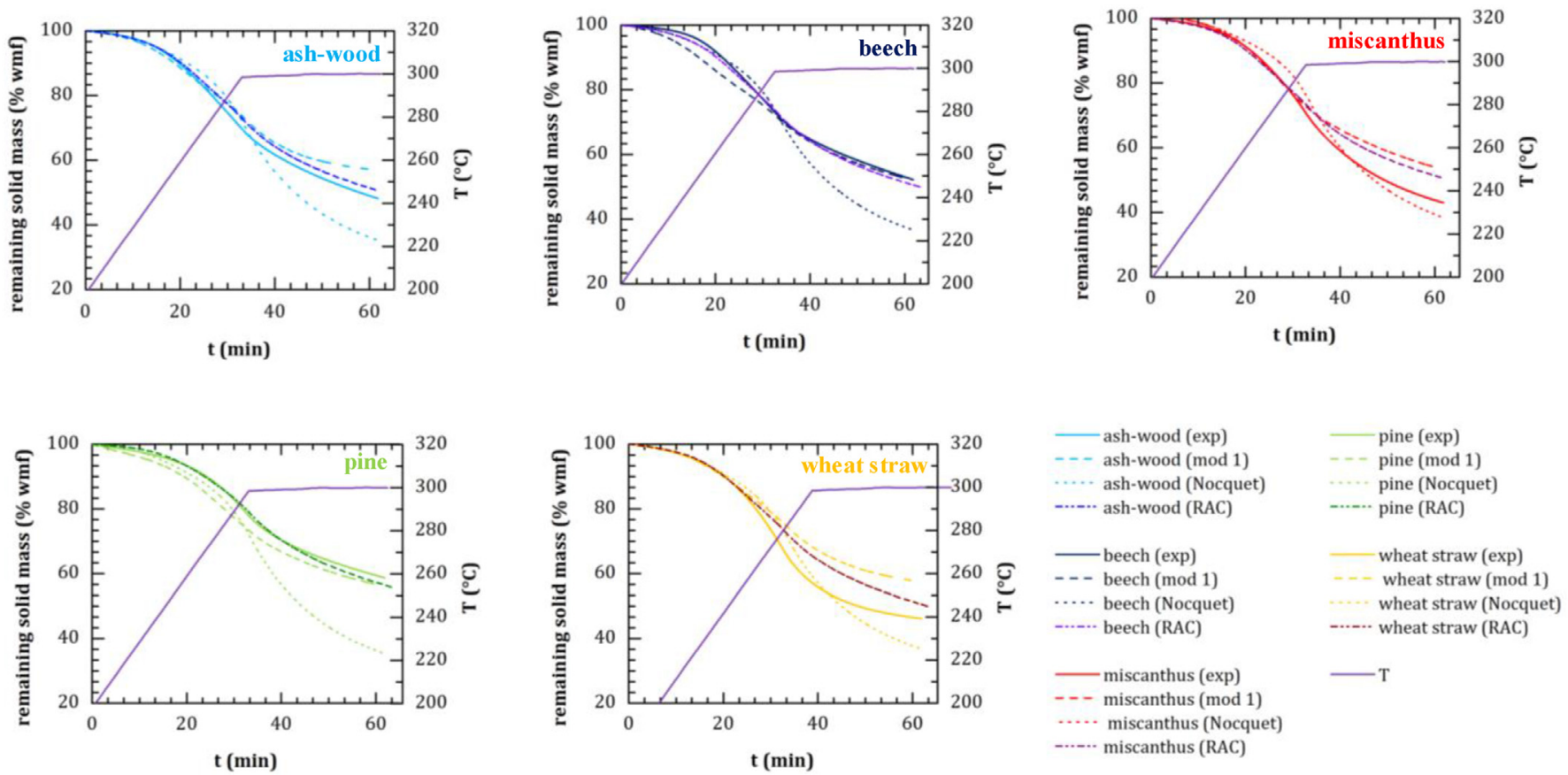

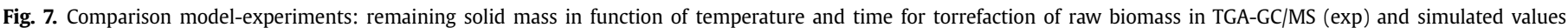
obtained through the proposed torrefaction model $(\bmod 1)$, Nocquet's model and Ranzi-Anca-Couce's (RAC) model.

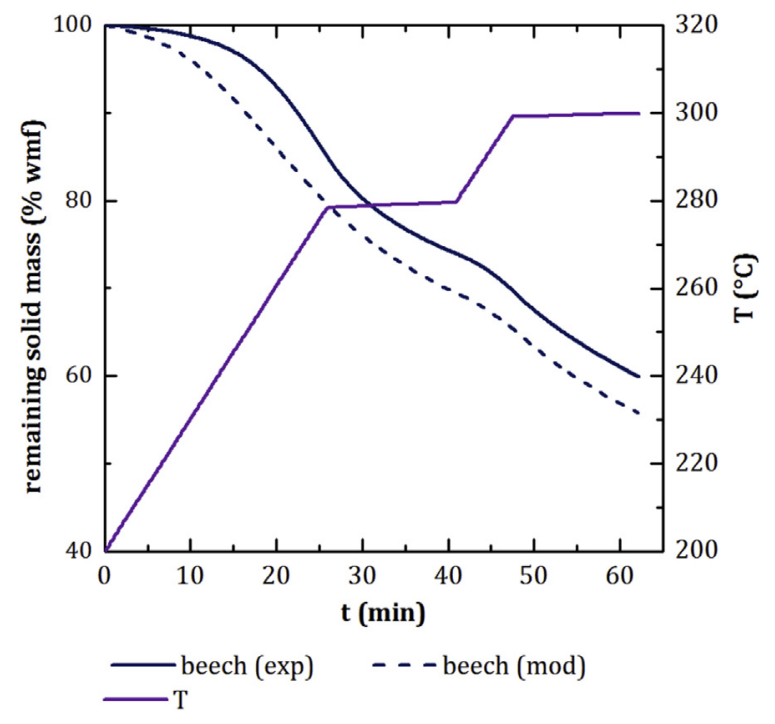

Fig. 8. Remaining solid mass loss in function of temperature and time during torrefaction by the first-level model (dotted line) and the experimental data (continuous line) for beech in TGA-GC/MS.

conversion in the second stage (isothermal), compared to the experiments. Furthermore, the consideration of specific torrefaction models per biomass family contributed to better take into account the specific behavior of each biomass in torrefaction due to their biologic origin. This was manifested by the different shape of the degradation profiles in function of the biomass family for the proposed model, which lead to a better fitting of the experimental data. The Nocquet's model presented a very similar shape for all biomasses, due to the fact that only slight differences exist on cellulose, hemicelluloses and lignin content for the biomasses of study.

The RAC model leads to similar predictions than the second- level novel model presented in this work. The bigger deviations were as well present in the second stage (isothermal) of nonwoody biomass. The RAC model was previously validated for torrefaction of woody biomass [51] and the present work showed again that torrefaction of hardwood and softwood species were well described. The predictions for pine were better than in the new model from this work during the first stage, which points out the complexity of hemicellulose in softwood. For other non-woody species, the deviations increased in the latter stage dominated by cellulose decomposition. As for the model presented in this work, the presence of inorganics or extractives could be an explanation of this discrepancy. Besides, the results from this work showed that in most of the cases mass loss in biomass torrefaction can be described by the addition of mass losses of extracted fractions. Thus, this concept can be employed in the future to investigate the release of volatile species, eventually employing the data for further

Table 8

Biomass main macromolecular composition as considered for the torrefaction model simulations.

\begin{tabular}{llll}
\hline Macromolecular component & Cellulose & Hemicelluloses & Lignin \\
\hline Extracted fractions considered for the torrefaction model & $\mathrm{C}^{\mathrm{II}}$ & $\mathrm{H}_{1}$ & \\
1st level model & $\mathrm{C}^{\mathrm{I}}$ & $\mathrm{H}_{\mathrm{T}}$ & $\mathrm{L}$ \\
2nd level model & \%wmf & & $\mathrm{L}$ \\
Raw biomass composition & & & \\
Deciduous wood & 46.7 & 23.8 & 29.4 \\
Poplar & 48.2 & 24.6 & 27.3 \\
Willow & & & \\
Coniferous wood & 28.7 & 36.0 & 35.3 \\
Pine forest residues & 27.0 & 22.6 & 50.3 \\
Scot pine bark & & & \\
Herbaceous crops & 43.9 & 28.6 & 27.5 \\
Reed canary grass & & & \\
Agricultural by-products & 43.1 & 39.1 & 67.8 \\
Corn cob & 8.4 & 23.7 & 29.0 \\
Grape seed cake & 41.5 & 29.5 & 26.3 \\
Sunflower seed shells & 44.7 & 28.9 & \\
Wheat straw (Swedish) & & & \\
\hline
\end{tabular}




\section{Deciduous wood (ash-wood model)}

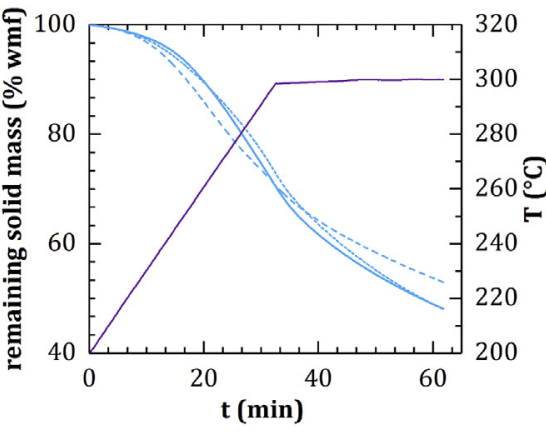

- beech (exp)

- - - beech(ash-wood model v1)

beech (ash-wood model v2)

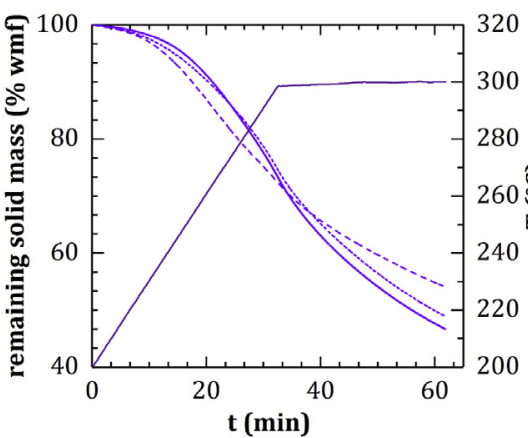

poplar (exp)

- - - - poplar (ash-wood model v1)

-.-.-. poplar (ash-wood model v2)

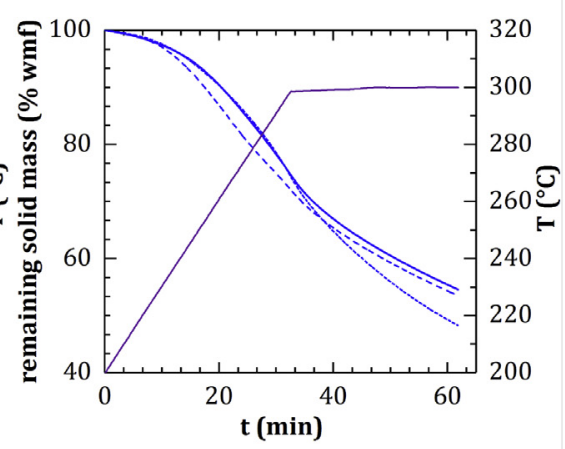

willow (exp)

-- - - willow (ash-wood model v1)

..--.-.-... willow (ash-wood model v2)

\section{Deciduous wood (beech model)}
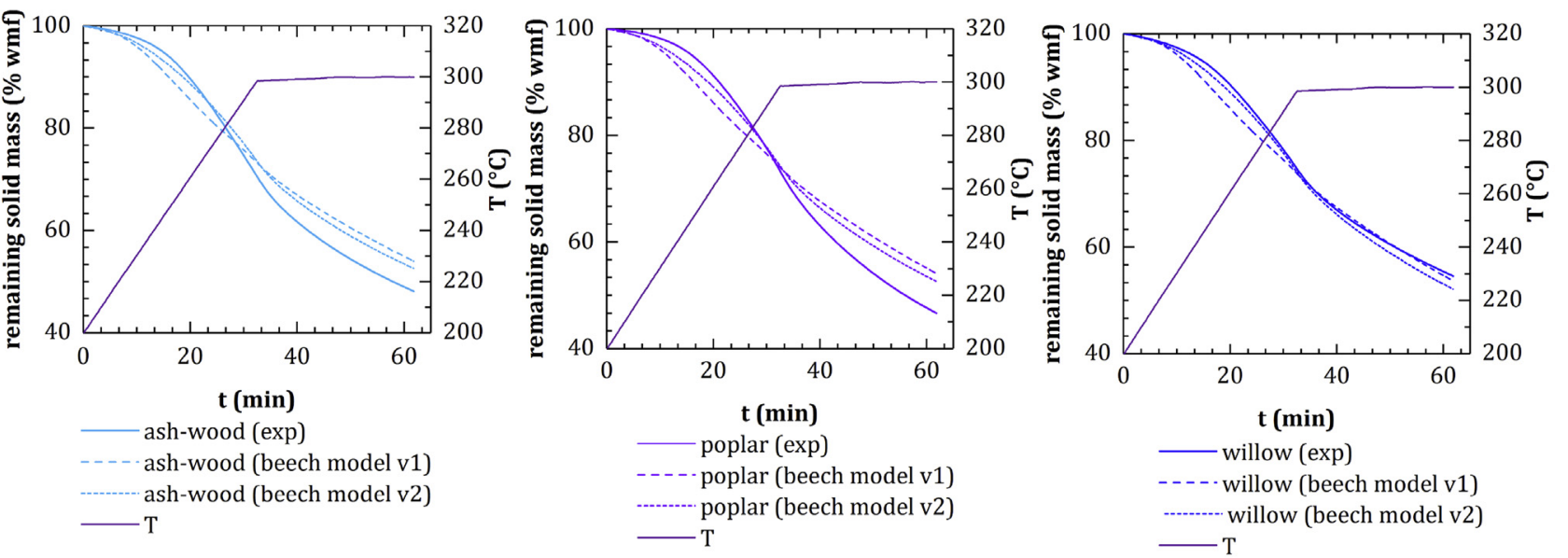

\section{Coniferous wood (pine model)}

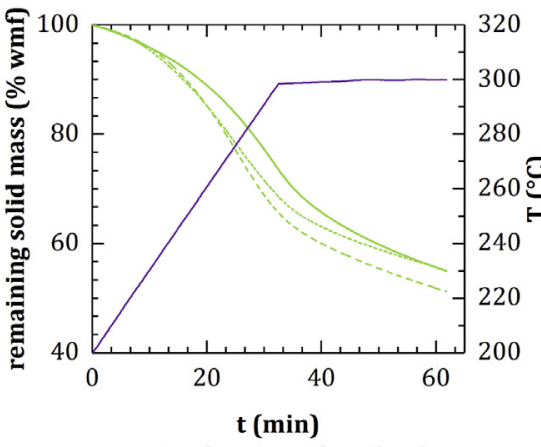

pine forest residues (exp)

pine forest residues (pine model v1) pine forest residues (pine model v2)

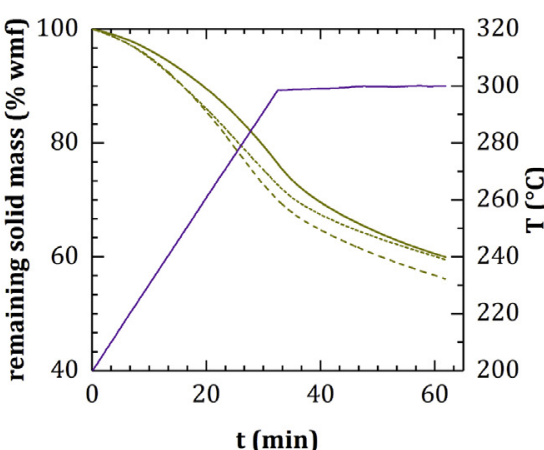

Scot pine bark (exp)

- - - Scot pine bark (pine model v1)

---.-- Scot pine bark (pine model v2) $\mathrm{T}$

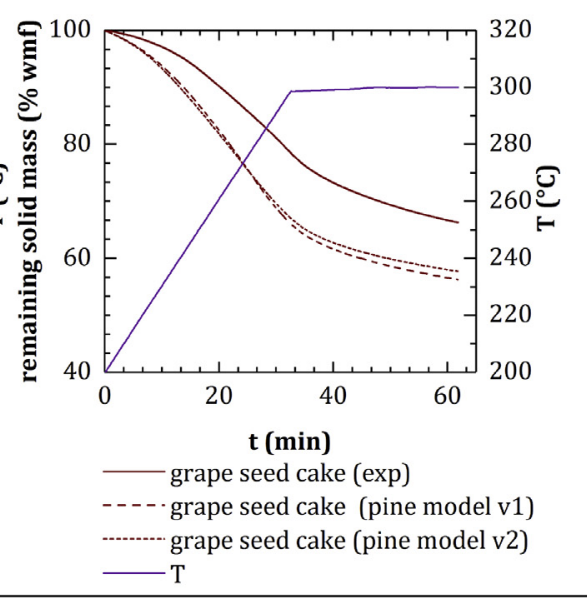




\section{Herbaceous crops (miscanthus model)}

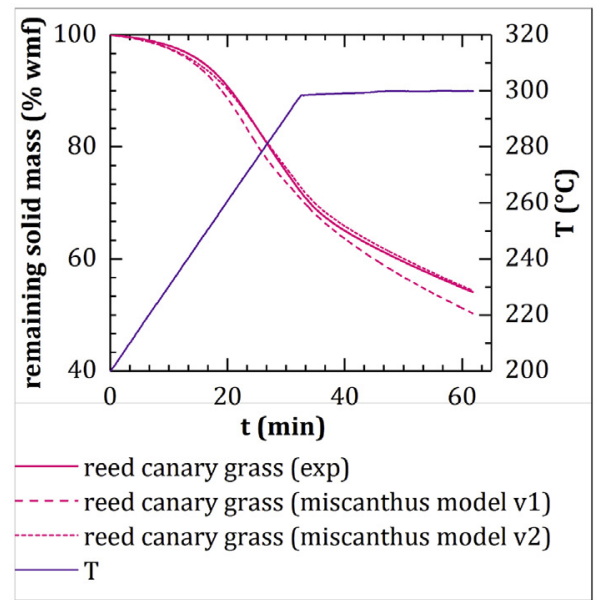

\section{Agricultural by-products (wheat straw model)}

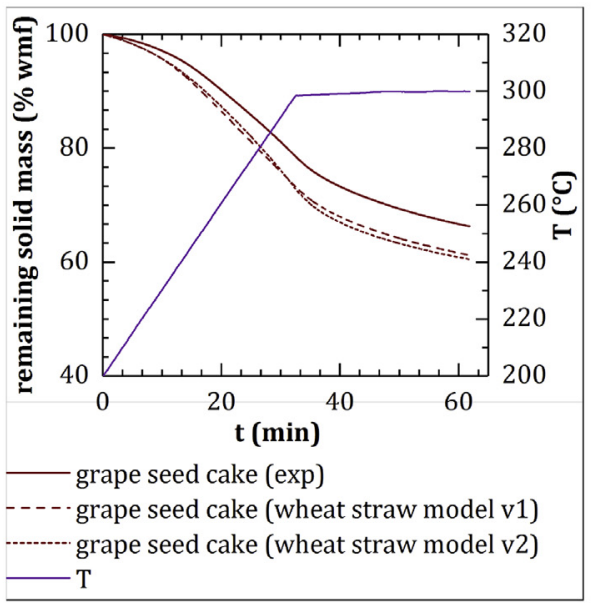

\section{Agricultural by-products (wheat straw model)}

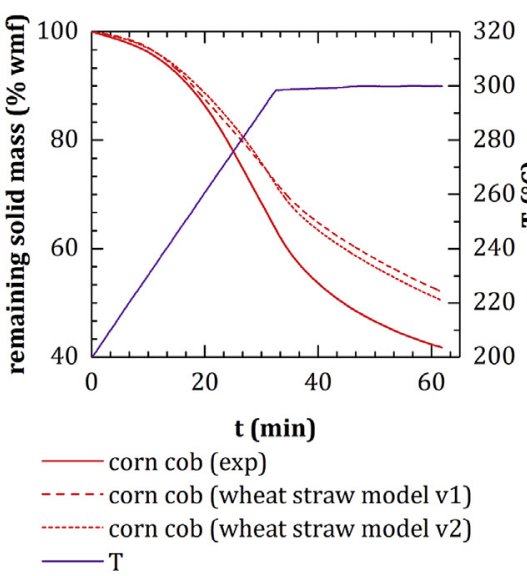

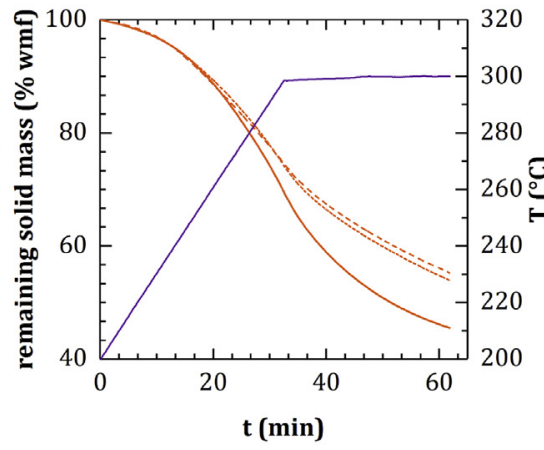

sunflower shells (exp)

- - - - sunflower shells (wheat straw model v1) sunflower shells (wheat straw model v2) T

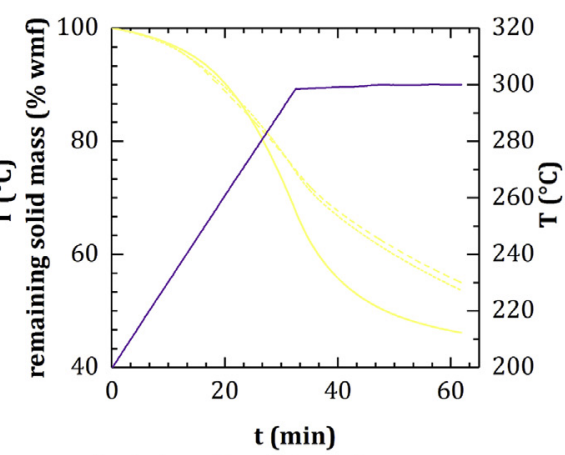

wheat straw (Swedish, exp)

wheat straw (Swedish, wheat straw model v1) wheat straw (Swedish, wheat straw model v2) model developments.

In conclusion, modelling biomass torrefaction through the extracted macromolecular compounds was shown to be a more accurate approach, compared to previous studies using commercial compounds. While the first-level model is based on more accurate experimental data, the second-level model offers an even improved prediction of biomass behavior in torrefaction, even if some uncertainty still remains on its construction. Furthermore, an advantage of the proposed torrefaction model is its specificity for biomass type.

\subsection{Validation of the model}

\subsubsection{Predictive feature of the modelling}

The dynamic prediction of biomass behavior in torrefaction through the first-level model in function of time and temperature was tested for beech under different operating conditions from those established for kinetic parameters fitting. Torrefaction new operating conditions consisted of a dynamic heating at $3{ }^{\circ} \mathrm{C} \cdot \mathrm{min}^{-1}$ interrupted by two isothermal steps of $30 \mathrm{~min}$ at 280 and $300{ }^{\circ} \mathrm{C}$ (Fig. 8).

Solid kinetics were slightly overestimated by the model in the whole temperature range. However, the order of magnitude of the mass loss overestimation remained in the range of experimental uncertainties $(<8 \%)$ and this overestimation took place as well for this species with the previous heating program employed for the derivation of kinetics.

\subsubsection{Extrapolation of the model}

The proposed torrefaction model was applied to predict the behavior in torrefaction of nine woody and agricultural species presented in Ref. [76]. Biomass family was used to select the suitable torrefaction model (deciduous wood, coniferous wood, agricultural by-products and herbaceous crops). Raw biomass composition in cellulose, hemicelluloses and lignin was then introduced in the model (Table 8). Modelling results are presented 
in Table 9. First- and second-level versions of the torrefaction model were considered and the mean absolute and relative errors in the prediction were calculated (Supplementary Material, Table S1).

In the case of deciduous wood, the two proposed models, based on ash-wood and beech, were validated, leading to equivalent results. This validated the hypothesis of selecting a single biomass per family in this case. A better prediction was achieved with the second-level model compared to the first-level one. In all cases, the maximum relative error at a given temperature was around 16\% and corresponded to isothermal torrefaction at $300{ }^{\circ} \mathrm{C}$, except for willow which is lower.

Remaining solid mass prediction for coniferous wood using pine torrefaction model was correct both in non-isothermal and isothermal torrefaction steps. The maximum relative error corresponded to solid kinetics estimation around $300{ }^{\circ} \mathrm{C}(<10 \%)$. Grape seed cake kinetics in torrefaction were also evaluated through this model, as it presented a high lignin content like coniferous wood (Table 8). In this case, grape seed cake remaining solid mass was overestimated in the whole torrefaction temperature range (maximum relative error around 16\%). This result reminded the importance of both considering biomass family, namely woody or agricultural biomass, as well as its macromolecular composition, when modelling biomass behavior in torrefaction.

An accurate prediction of reed canary grass behavior was achieved thanks to the herbaceous crop model based on miscanthus, as the relative error was below $2 \%$ for the second-level model.

In the case of agricultural biomasses, both model levels led to a maximum overestimation of the remaining solid mass around $25 \%$. However, remaining solid mass for grape seed cake was underestimated. For this biomass, the relative error obtained on the prediction through the agricultural biomass model was below $10 \%$, which was lower than that for coniferous wood model. This might indicate a crucial role of interactions between macromolecular components and possibly with inorganics in agricultural biomass, and the need to represent them in torrefaction models. The similar underestimation for corn cob, sunflower shells and the Swedish wheat straw might indicate them as a sub-family of agricultural biomasses, corresponding to cereal derivatives, and different to grape seed cake, which could be classified as lignin-rich biomass. This supported the need of defining sub-divisions in such a diverse group of biomasses as agricultural crops, so as to better define their behavior in torrefaction. The proposed wheat straw model is acceptable for cereal derivatives. However, complementary models would need to be developed for other sub-groups of agricultural biomasses, such as lignin-rich crops, as it is the case of grape seed cake.

\section{Conclusions}

A torrefaction model based on the additive contribution of the behavior of cellulose, hemicellulose and lignin fractions extracted from five woody and agricultural biomasses was proposed. The model depended also on the biomass family. A more accurate representation of the solid mass loss kinetics during torrefaction was achieved with this model compared to previous models based on commercial compounds. This improvement was especially remarkable for deciduous (ash-wood and beech) and coniferous (pine) wood, while the representation was less accurate for agricultural biomasses (represented by wheat straw) or herbaceous biomass (represented by miscanthus) during the latter stages of torrefaction. Hemicelluloses, whose composition is crucial in agricultural biomasses, are the determinant macromolecular component in biomass degradation through torrefaction. However, it is challenging to produce hemicellulose extracted fractions which correctly preserve the complexity of the native hemicelluloses in biomass. Furthermore, the uncertainty in sugar characterization may also influence errors in biomass representation, especially for agricultural biomasses or softwood.

The consideration of different biomasses, as well as of their extracted macromolecular components, demonstrated that biomass behavior in torrefaction is also dependent on biomass type. However, biomass morphology at the micrometer scale, as well as pore size and distribution may also influence its behavior in torrefaction. As a result, the use of one or several sets of model parameter values per biomass family (woods, agricultural byproducts, herbaceous crops) and sub-families (i.e. deciduous and coniferous woods) was justified. A more detailed biomass characterization, as well as a subdivision in the agricultural biomasses group (i.e. cereal derivatives, lignin-rich derivatives), eventually considering inorganics or extractives, may enable to keep on improving the understanding and modelling of the mechanisms involved in biomass torrefaction. The proposed approach in this work can as well be employed to investigate the release of volatiles during torrefaction.

\section{Credit author statement}

María González Martínez: Conceptualization; Investigation; Formal analysis; Methodology; Visualization; Writing - original draft; Capucine Dupont: Conceptualization; Supervision; Project administration; Funding acquisition; Andrés Anca Couce: Writing review \& editing; Denilson da Silva Perez: Conceptualization; Methodology; Resources; Investigation; Gérard Mortha: Resources; Investigation; Sébastien Thiéry: Investigation; Xuân-mi Meyer: Methodology; Supervision; Validation; Christophe Gourdon: Methodology; Supervision; Validation.

\section{Declaration of competing interest}

The authors declare that they have no known competing financial interests or personal relationships that could have appeared to influence the work reported in this paper.

\section{Acknowledgments}

This project has received funding from the European Union's Horizon 2020 research and innovation program under grant agreement No 637020-MOBILE FLIP. The Université Fédérale de Toulouse Midi-Pyrénées (France) is also acknowledged for the support of this work.

\section{Appendix A. Supplementary data}

Supplementary data to this article can be found online at https://doi.org/10.1016/j.energy.2020.118451.

\section{References}

[1] Chen W-H, Peng J, Bi XT. A state-of-the-art review of biomass torrefaction, densification and applications. Renew Sustain Energy Rev 2015;44:847-66. https://doi.org/10.1016/j.rser.2014.12.039.

[2] Li M-F, Li X, Bian J, Chen C-Z, Yu Y-T, Sun R-C. Effect of temperature and holding time on bamboo torrefaction. Biomass Bioenergy 2015;83:366-72. https://doi.org/10.1016/j.biombioe.2015.10.016.

[3] Nocquet T, Dupont C, Commandre J-M, Grateau M, Thiery S, Salvador S. Volatile species release during torrefaction of wood and its macromolecular constituents: Part 1 - experimental study. Energy 2014;72:180-7. https:// doi.org/10.1016/j.energy.2014.02.061.

[4] Wannapeera J, Fungtammasan B, Worasuwannarak N. Effects of temperature and holding time during torrefaction on the pyrolysis behaviors of woody biomass. J Anal Appl Pyrolysis 2011;92:99-105. https://doi.org/10.1016/ j.jaap.2011.04.010. 
[5] Chen D, Gao A, Cen K, Zhang J, Cao X, Ma Z. Investigation of biomass torrefaction based on three major components: hemicellulose, cellulose, and lignin Energy Convers Manag 2018;169:228-37. https://doi.org/10.1016| j.enconman.2018.05.063.

[6] Chen W-H, Kuo P-C. Isothermal torrefaction kinetics of hemicellulose, cellulose, lignin and xylan using thermogravimetric analysis. Energy 2011;36: 6451-60. https://doi.org/10.1016/j.energy.2011.09.022.

[7] Prins MJ, Ptasinski KJ, Janssen FJJG. Torrefaction of wood: Part 1. Weight loss kinetics. J Anal Appl Pyrolysis 2006;77:28-34. https://doi.org/10.1016/ j.jaap.2006.01.002.

[8] Khazraie Shoulaifar T, DeMartini N, Karlström O, Hupa M. Impact of organically bonded potassium on torrefaction: Part 1. Experimental, Fuel 2016;165: 544-52. https://doi.org/10.1016/j.fuel.2015.06.024.

[9] de Macedo LA, Commandré J-M, Rousset P, Valette J, Pétrissans M. Influence of potassium carbonate addition on the condensable species released during wood torrefaction. Fuel Process Technol 2018;169:248-57. https://doi.org/ 10.1016/j.fuproc.2017.10.012.

[10] Zhang S, Su Y, Ding K, Zhu S, Zhang H, Liu X, Xiong Y. Effect of inorganic species on torrefaction process and product properties of rice husk. Bioresour Technol 2018;265:450-5. https://doi.org/10.1016/j.biortech.2018.06.042.

[11] Guo X, Wang S, Wang K, Liu Q, Luo Z. Influence of extractives on mechanism of biomass pyrolysis. J Fuel Chem Technol 2010;38:42-6. https://doi.org/ 10.1016/S1872-5813(10)60019-9.

[12] Moya R, Rodríguez-Zúñiga A, Puente-Urbina A, Gaitán-Álvarez J. Study of light, middle and severe torrefaction and effects of extractives and chemical compositions on torrefaction process by thermogravimetric analysis in five fast-growing plantations of Costa Rica. Energy 2018;149:1-10. https:/ doi.org/10.1016/j.energy.2018.02.049.

[13] Dupont C, Jacob S, Marrakchy KO, Hognon C, Grateau M, Labalette F, Da Silva Perez D. How inorganic elements of biomass influence char steam gasification kinetics. Energy 2016;109:430-5. https://doi.org/10.1016 j.energy.2016.04.094.

[14] Romero Millán LM, Sierra Vargas FE, Nzihou A. Steam gasification behavior of tropical agrowaste: a new modeling approach based on the inorganic composition. Fuel 2019;235:45-53. https://doi.org/10.1016/ j.fuel.2018.07.053.

[15] Kleen M, Gellerstedt G. Influence of inorganic species on the formation of polysaccharide and lignin degradation products in the analytical pyrolysis of pulps. J Anal Appl Pyrolysis 1995;35:15-41. https://doi.org/10.1016/01652370(95)00893-J.

[16] Anca-Couce A. Reaction mechanisms and multi-scale modelling of lignocellulosic biomass pyrolysis. Prog Energy Combust Sci 2016;53:41-79. https:// doi.org/10.1016/j.pecs.2015.10.002.

[17] Collard F-X, Blin J. A review on pyrolysis of biomass constituents: mechanisms and composition of the products obtained from the conversion of cellulose, hemicelluloses and lignin. Renew Sustain Energy Rev 2014;38:594-608. https://doi.org/10.1016/j.rser.2014.06.013.

[18] Papari S, Hawboldt K. A review on the pyrolysis of woody biomass to bio-oil: focus on kinetic models. Renew Sustain Energy Rev 2015;52:1580-95. https://doi.org/10.1016/j.rser.2015.07.191.

[19] Wang S, Ru B, Lin H, Dai G, Wang Y, Luo Z. Kinetic study on pyrolysis of biomass components: a critical review. Curr Org Chem 2016;20. https:// doi.org/10.2174/1385272820666160525115832. 1-1.

[20] Wang S, Dai G, Yang H, Luo Z. Lignocellulosic biomass pyrolysis mechanism: a state-of-the-art review. Prog Energy Combust Sci 2017;62:33-86. https:/ doi.org/10.1016/j.pecs.2017.05.004.

[21] Cheng K, Winter WT, Stipanovic AJ. A modulated-TGA approach to the kinetics of lignocellulosic biomass pyrolysis/combustion. Polym Degrad Stabil 2012;97:1606-15. https://doi.org/10.1016/j.polymdegradstab.2012.06.027.

[22] Di Blasi C. Modeling chemical and physical processes of wood and biomass pyrolysis. Prog Energy Combust Sci 2008;34:47-90. https://doi.org/10.1016 j.pecs.2006.12.001.

[23] Rousset P, Turner I, Donnot A, Perré P. Choix d'un modèle de pyrolyse ménagée du bois à l'échelle de la microparticule en vue de la modélisation macroscopique. Ann For Sci 2006;63:17. https://doi.org/10.1051/forest: 2005113.

[24] Shafizadeh F. Introduction to pyrolysis of biomass. J Anal Appl Pyrolysis 1982;3:283-305. https://doi.org/10.1016/0165-2370(82)80017-X.

[25] Lédé J. Cellulose pyrolysis kinetics: an historical review on the existence and role of intermediate active cellulose. J Anal Appl Pyrolysis 2012;94:17-32. https://doi.org/10.1016/j.jaap.2011.12.019.

[26] Mettler MS, Paulsen AD, Vlachos DG, Dauenhauer PJ. Pyrolytic conversion of cellulose to fuels: levoglucosan deoxygenation via elimination and cyclization within molten biomass. Energy Environ Sci 2012;5:7864-8. https://doi.org/ 10.1039/C2EE21305B

[27] Koufopanos CA, Lucchesi A, Maschio G. Kinetic modelling of the pyrolysis of biomass and biomass components. Can J Chem Eng 1989;67:75-84. https:// doi.org/10.1002/cjce.5450670111.

[28] Di Blasi C, Lanzetta M. Intrinsic kinetics of isothermal xylan degradation in inert atmosphere. J Anal Appl Pyrolysis 1997;40-41:287-303. https://doi.org 10.1016/S0165-2370(97)00028-4.

[29] Nocquet T, Dupont C, Commandre J-M, Grateau M, Thiery S, Salvador S. Volatile species release during torrefaction of biomass and its macromolecula constituents: Part 2 - modeling study. Energy 2014;72:188-94. https:// doi.org/10.1016/j.energy.2014.05.023.
[30] Branca C, Blasi CD, Mango C, Hrablay I. Products and kinetics of glucomannan pyrolysis. 2013. https://doi.org/10.1021/ie400155x.

[31] Grønli MG, Várhegyi G, Di Blasi C. Thermogravimetric analysis and devolatilization kinetics of wood. Ind Eng Chem Res 2002;41:4201-8. https://doi.org/ 10.1021/ie0201157.

[32] Broström M, Nordin A, Pommer L, Branca C, Di Blasi C. Influence of torrefaction on the devolatilization and oxidation kinetics of wood. J Anal Appl Pyrolysis 2012;96:100-9. https://doi.org/10.1016/j.jaap.2012.03.011.

[33] Prins MJ, Ptasinski KJ, Janssen FJJG. Torrefaction of wood. Part 2. Analysis of products. J Anal Appl Pyrolysis 2006;77:35-40. https://doi.org/10.1016/ j.jaap.2006.01.001.

[34] Bates RB, Ghoniem AF. Biomass torrefaction: modeling of volatile and solid product evolution kinetics. Bioresour Technol 2012;124:460-9. https:// doi.org/10.1016/j.biortech.2012.07.018.

[35] Gonzalez-Quiroga A, Van Geem KM, Marin GB. Towards first-principles based kinetic modeling of biomass fast pyrolysis. Biomass Convers. Biorefinery. 2017;7:305-17. https://doi.org/10.1007/s13399-017-0251-0.

[36] Vinu R, Broadbelt LJ. A mechanistic model of fast pyrolysis of glucose-based carbohydrates to predict bio-oil composition. Energy Environ Sci 2012;5: 9808-26. https://doi.org/10.1039/C2EE22784C.

[37] Klein MT, Virk PS. Modeling of lignin thermolysis. Energy Fuels 2008;22: 2175-82. https://doi.org/10.1021/ef800285f.

[38] Horton SR, Mohr RJ, Zhang Y, Petrocelli FP, Klein MT. Molecular-level kinetic modeling of biomass gasification. Energy Fuels 2016;30:1647-61. https:// doi.org/10.1021/acs.energyfuels.5b01988.

[39] Norinaga K, Shoji T, Kudo S, Hayashi J. Detailed chemical kinetic modelling of vapour-phase cracking of multi-component molecular mixtures derived from the fast pyrolysis of cellulose. Fuel 2013;103:141-50. https://doi.org/10.1016/ j.fuel.2011.07.045.

[40] Thimthong N, Appari S, Tanaka R, Iwanaga K, Kudo S, Hayashi J, Shoji T, Norinaga K. Kinetic modeling of non-catalytic partial oxidation of nascent volatiles derived from fast pyrolysis of woody biomass with detailed chemistry. Fuel Process Technol 2015;134:159-67. https://doi.org/10.1016/ j.fuproc.2015.01.029.

[41] Yang H-M, Appari S, Kudo S, Hayashi J, Norinaga K. Detailed chemical kinetic modeling of vapor-phase reactions of volatiles derived from fast pyrolysis of lignin. Ind Eng Chem Res 2015;54:6855-64. https://doi.org/10.1021/ acs.iecr.5b01289.

[42] Mayes HB, Broadbelt LJ. Unraveling the reactions that unravel cellulose. J Phys Chem 2012;116:7098-106. https://doi.org/10.1021/jp300405x.

[43] Ranzi E, Cuoci A, Faravelli T, Frassoldati A, Migliavacca G, Pierucci S, Sommariva S. Chemical kinetics of biomass pyrolysis. Energy Fuels 2008;22: 4292-300. https://doi.org/10.1021/ef800551t.

[44] Corbetta M, Frassoldati A, Bennadji H, Smith K, Serapiglia MJ, Gauthier G, Melkior T, Ranzi E, Fisher EM. Pyrolysis of centimeter-scale woody biomass particles: kinetic modeling and experimental validation. Energy Fuels 2014;28:3884-98. https://doi.org/10.1021/ef500525v.

[45] Cuoci A, Faravelli T, Frassoldati A, Granata S, Migliavacca G, Ranzi E, Sommariva S. A general mathematical model of biomass devolatilization. Note 1. Lumped kinetic models of cellulose. hemicellulose and lignin.; 2007.

[46] Cuoci A, Faravelli T, Frassoldati A, Granata S, Migliavacca G, Pierucci S, Ranzi E, Sommariva S. A general mathematical model of biomass devolatilization note 2. Detailed kinetics of volatile species. 2007.

[47] Ranzi E, Corbetta M, Manenti F, Pierucci S. Kinetic modeling of the thermal degradation and combustion of biomass. Chem Eng Sci 2014;110:2-12. https://doi.org/10.1016/j.ces.2013.08.014

[48] Debiagi PEA, Pecchi C, Gentile G, Frassoldati A, Cuoci A, Faravelli T, Ranzi E. Extractives extend the applicability of multistep kinetic scheme of biomass pyrolysis. Energy Fuels 2015;29:6544-55. https://doi.org/10.1021/ acs.energyfuels.5b01753.

[49] Anca-Couce A, Mehrabian R, Scharler R, Obernberger I. Kinetic scheme of biomass pyrolysis considering secondary charring reactions. Energy Convers Manag 2014;87:687-96. https://doi.org/10.1016/j.enconman.2014.07.061.

[50] Anca-Couce A, Sommersacher P, Scharler R. Online experiments and modelling with a detailed reaction scheme of single particle biomass pyrolysis. J Anal Appl Pyrolysis 2017;127:411-25. https://doi.org/10.1016/ j.jaap.2017.07.008.

[51] Anca-Couce A, Obernberger I. Application of a detailed biomass pyrolysis kinetic scheme to hardwood and softwood torrefaction. Fuel 2016;167:158-67. https://doi.org/10.1016/j.fuel.2015.11.062.

[52] Dussan K, Dooley S, Monaghan R. Integrating compositional features in model compounds for a kinetic mechanism of hemicellulose pyrolysis. Chem Eng J 2017;328:943-61. https://doi.org/10.1016/j.cej.2017.07.089.

[53] Dussan K, Dooley S, Monaghan RFD. A model of the chemical composition and pyrolysis kinetics of lignin. Proc Combust Inst 2018. https://doi.org/10.1016/ j.proci.2018.05.149.

[54] González Martínez M, Dupont C, da Silva Perez D, Mortha G, Thiéry S, Meyer X, Gourdon C. Understanding the torrefaction of woody and agricultural biomasses through their extracted macromolecular components. Part 1: experimental thermogravimetric solid mass loss. Energy 2020;205:118067. https://doi.org/10.1016/j.energy.2020.118067.

[55] Broido A. A simple, sensitive graphical method of treating thermogravimetric analysis data. J. Polym. Sci. Part -2 Polym. Phys. 1969;7:1761-73. https:// doi.org/10.1002/pol.1969.160071012.

[56] Broido A, Nelson MA. Char yield on pyrolysis of cellulose. Combust Flame 
1975;24:263-8. https://doi.org/10.1016/0010-2180(75)90156-X.

[57] Arseneau DF. Competitive reactions in the thermal decomposition of cellulose. Can J Chem 1971;49:632-8. https://doi.org/10.1139/v71-101.

[58] Várhegyi G, Jakab E, Antal MJ. Is the broido-shafizadeh model for cellulose pyrolysis true? Energy Fuels 1994;8:1345-52. https://doi.org/10.1021/ ef00048a025.

[59] Shafizadeh F, Chin PPS. Thermal deterioration of wood. In: Wood technol. Chem. Asp. American Chemical Society; 1977. p. 57-81. https://doi.org/ 10.1021/bk-1977-0043.ch005. . [Accessed 29 April 2016].

[60] Di Blasi C, Branca C. Kinetics of primary product formation from wood pyrolysis. Ind Eng Chem Res 2001;40:5547-56. https://doi.org/10.1021/ ie000997e.

[61] Bradbury AGW, Sakai Y, Shafizadeh F. A kinetic model for pyrolysis of cellulose. J Appl Polym Sci 1979;23:3271-80. https://doi.org/10.1002/ app.1979.070231112.

[62] Thurner F, Mann U. Kinetic investigation of wood pyrolysis. Ind Eng Chem Process Des Dev 1981;20:482-8. https://doi.org/10.1021/i200014a015.

[63] Chan W-CR, Kelbon M, Krieger BB. Modelling and experimental verification of physical and chemical processes during pyrolysis of a large biomass particle. Fuel 1985;64:1505-13. https://doi.org/10.1016/0016-2361(85)90364-3.

[64] Ratte J, Marias F, Vaxelaire J, Bernada P. Mathematical modelling of slow pyrolysis of a particle of treated wood waste. J Hazard Mater 2009;170: 1023-40. https://doi.org/10.1016/j.jhazmat.2009.05.077.

[65] Repellin V, Govin A, Rolland M, Guyonnet R. Energy requirement for fine grinding of torrefied wood. Biomass Bioenergy 2010;34:923-30. https:/| doi.org/10.1016/j.biombioe.2010.01.039.

[66] Shang L, Ahrenfeldt J, Holm JK, Barsberg S, Zhang R, Luo Y, Egsgaard H, Henriksen UB. Intrinsic kinetics and devolatilization of wheat straw during torrefaction. J Anal Appl Pyrolysis 2013;100:145-52. https://doi.org/10.1016/ j.jaap.2012.12.010.

[67] Piskorz J, Radlein D, Scott DS. On the mechanism of the rapid pyrolysis of cellulose. J Anal Appl Pyrolysis 1986;9:121-37. https://doi.org/10.1016/01652370(86)85003-3.

[68] Agrawal RK. Kinetics of reactions involved in pyrolysis of cellulose I. The three reaction model. Can J Chem Eng 1988;66:403-12. https://doi.org/10.1002/ cjce.5450660309.
[69] Agrawal RK. Kinetics of reactions involved in pvrolvsis of cellulose II. The modified kilzer-bioid model. Can J Chem Eng 1988;66:413-8. https://doi.org/ 10.1002 /cjce.5450660310.

[70] Prins MJ, Ptasinski KJ, Janssen FJJG. More efficient biomass gasification via torrefaction. Energy 2006;31:3458-70. https://doi.org/10.1016 j.energy.2006.03.008.

[71] Peduzzi E, Boissonnet G, Haarlemmer G, Dupont C, Maréchal F. Torrefaction modelling for lignocellulosic biomass conversion processes. Energy 2014;70 58-67. https://doi.org/10.1016/j.energy.2014.03.086.

[72] Banyasz JL, Li S, Lyons-Hart JL, Shafer KH. Cellulose pyrolysis: the kinetics of hydroxyacetaldehyde evolution. J Anal Appl Pyrolysis 2001;57:223-48. https://doi.org/10.1016/S0165-2370(00)00135-2.

[73] Klinger J, Bar-Ziv E, Shonnard D. Kinetic study of aspen during torrefaction. J Anal Appl Pyrolysis 2013;104:146-52. https://doi.org/10.1016/ j.jaap.2013.08.010.

74] Klinger J, Bar-Ziv E, Shonnard D. Unified kinetic model for torrefaction-pyrolysis. Fuel Process Technol 2015;138:175-83. https://doi.org/ 10.1016/j.fuproc.2015.05.010.

[75] Anca-Couce A, Mehrabian R, Scharler R, Obernberger I. Kinetic scheme to predict product composition of biomass torrefaction. Chem. Eng. Trans. 2014;37:43-8. https://doi.org/10.3303/CET1437008.

[76] González Martínez M, Dupont C, Thiéry S, Meyer X-M, Gourdon C. Impact of biomass diversity on torrefaction: study of solid conversion and volatile species formation through an innovative TGA-GC/MS apparatus. Biomass Bioenergy 2018;119:43-53. https://doi.org/10.1016/j.biombioe.2018.09.002.

[77] Ebringerová A, Hromádková Z, Heinze T. Hemicellulose. In: Heinze T, editor Polysacch. I. Springer Berlin Heidelberg; 2005. p. 1-67. https://doi.org $10.1007 / \mathrm{b} 136816$.

[78] Scheller HV, Ulvskov P, Hemicelluloses. Annu Rev Plant Biol 2010;61:263-89. https://doi.org/10.1146/annurev-arplant-042809-112315.

[79] Harris PJ. Primary and secondary plant cell walls: a comparative overview. N Z J For Sci 2006:36-53.

[80] Almuina-Villar H, Lang N, Anca-Couce A, Röpcke J, Behrendt F, DieguezAlonso A. Application of laser-based diagnostics for characterization of the influence of inorganics on the slow pyrolysis of woody biomass. J Anal Appl Pyrolysis 2019;140:125-36. https://doi.org/10.1016/j.jaap.2019.03.004. 